\title{
Article
}

\section{Piston-ring film thickness: theory and experiment compared}

Garcia-Atance fatjo, Gonzalo, Smith, Edward H and Sherrington, Ian Available at http://clok.uclan.ac.uk/18550/

Garcia-Atance fatjo, Gonzalo ORCID: 0000-0002-3914-7160, Smith, Edward H ORCID: 0000-0003-0093-4463 and Sherrington, Ian ORCID: 0000-0003-12839850 (2017) Piston-ring film thickness: theory and experiment compared. Proceedings of the Institution of Mechanical Engineers, Part J: Journal of Engineering Tribology, 232 (5). pp. 550-567. ISSN 1350-6501

It is advisable to refer to the publisher's version if you intend to cite from the work. http://dx.doi.org/10.1177/1350650117722257

For more information about UCLan's research in this area go to http://www.uclan.ac.uk/researchgroups/ and search for <name of research Group>.

For information about Research generally at UCLan please go to http://www.uclan.ac.uk/research/

All outputs in CLoK are protected by Intellectual Property Rights law, including Copyright law. Copyright, IPR and Moral Rights for the works on this site are retained by the individual authors and/or other copyright owners. Terms and conditions for use of this material are defined in the policies page.

\section{CLoK}

Central Lancashire online Knowledge www.clok.uclan.ac.uk

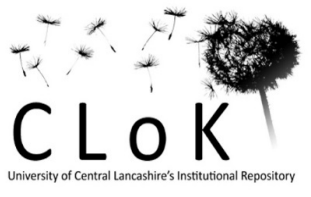




\title{
Piston-ring film thickness: theory and experiment compared
}

\section{Gonzalo Garcia-Atance Fatjo,}

\author{
Edward H. Smith,
}

Ian Sherrington

\author{
Jost Institute for Tribotechnology \\ University of Central Lancashire \\ Preston
}

PR1 2HE

UK

\begin{abstract}
A review of the published literature has demonstrated a large variability and discrepancies in the measured and predicted values of piston-ring lubricating film thickness in internal combustion engines. Only 2 papers have been found that compare experiments in firing engines directly with outputs from sophisticated ring-pack lubrication models. The agreement between theory and experiment in these comparisons was limited, possibly because of inadequacies in the models and/ or inaccuracies of measurement. This paper seeks to contribute to the literature by comparing accurately calibrated experimental measurements of piston-ring film thickness in a firing engine with predictions from an advanced, commercial software package alongside details of the systematic analysis of the measurement errors in this process. Suggestions on how measurement accuracy could be further improved are also given. Measurements of oil film thickness with an error (standard deviation) of $+/-15 \%$ have been achieved. It is shown that this error can be reduced further, by changes in the design and installation of the sensors.

Detailed experimental measurements of film thickness under the top compression ring in a firing petrol engine have been made and compared with the predictions from a commercial, state-of-the art modelling package. The agreement between theory and experiment is excellent throughout the stroke in most cases, but some significant differences are observed at the lower load conditions. These differences are as yet unexplained, but may be due to the sensor topography influencing the hydrodynamic lubrication, lubricant availability, out-of-roundness in the cylinder, or squeeze effects. This a topic that requires further study.
\end{abstract}


Keywords: Piston-ring lubrication; Oil film thickness measurement and simulation.

\section{Introduction}

The prediction and measurement of piston-ring film thickness in internal combustion engines has received attention from researchers for almost 60 years. The authors have examined 27 papers describing oil-film thickness (oft) measurements in firing engines, and found a wide variation in the magnitudes of the minimum and maximum filmthicknesses recorded. (Minimum and maximum film thicknesses are important because the former will occur around the dead-centre positions and indicate the likelihood of wear, whereas the latter generally occurs around mid-stroke where the hydrodynamic power loss will be greatest). The techniques employed for measuring film thickness in these papers range from measuring changes in the ring gap $(1,2)$ to direct measurements of the lubricating film using capacitance sensors, laser induced fluorescence (LIF) and ultrasonic methods. Sherrington $(3,4)$ provides a detailed critique of all measurement approaches. A summary of the measurements in range of publications is presented in Figure 1, where the minimum (around TDC) and maximum (around mid-stroke) recorded film thicknesses under the compression ring are plotted against cylinder capacity. Further details are included in the Appendix. Almost 90\% of the minimum film thickness data (Fig 1a) lie within the range $0 \mu \mathrm{m}$ to $2 \mu \mathrm{m}$, and there is no obvious correlation between film thickness and cylinder capacity or measurement approach. The maximum recorded film thicknesses, as presented in Figure 1(b), show a much wider spread, and again the measurement technique or the cylinder size has no effect. It might be thought that more recent research may show a reduced spread because of improvements in measuring techniques and a perceived reduction in the thickness of operating film thickness as manufacturing and design techniques develop. However, examination of the year of publication revealed this not to be the case.

Turning to theoretical models, these have progressed from single-ring, fully-flooded approaches (1) to full ring-pack simulations considering oil availability, ring-twist, secondary piston motion and surface roughness. The authors have examined results from 32 papers and Figure 2 shows that all minimum film thicknesses were predicted to be in the region of $0 \mu \mathrm{m}$ to $2 \mu \mathrm{m}$. This compares favorably with measured values. Virtually all predicted maxima lay within the range $1 \mu \mathrm{m}$ to $11 \mu \mathrm{m}$, with the smaller values tending to be for starved-inlet models. Overall, therefore, it would appear that theoretical models generally predict minimum film thicknesses of the same magnitude as those measured. When maximum film thicknesses are considered, predicted and actual mid-stroke values differ greatly. It is not clear whether this is due to limitations in modelling or inaccuracies in measuring, or a combination of the two.

To test the validity of a ring-pack model, its predictions should be compared with detailed and accurate experimental measurements. Only two of the papers reviewed sought to do this for a firing engine. One of these (5) included the effects of starvation and bore distortion and predicted a maximum compression-ring film thickness of $4 \mu \mathrm{m}$, but reported a measured value of $1.8 \mu \mathrm{m}$. The second (6) employed a commercial ring pack lubrication modelling package (which we believe considers starvation and ring- 
twist) and predicted minimum and maximum compression-ring film thicknesses of $0 \mu \mathrm{m}$ and $6 \mu \mathrm{m}$, in contrast to predictions of $6 \mu \mathrm{m}$ and $19 \mu \mathrm{m}$.

The major factors thought to influence piston ring oft are ring velocity (axial and radial), ring shape, the angle subtended by the ring to the cylinder wall, the load applied, and the viscosity and availability of the lubricant. There is also a view that bore distortion can have an effect if the rings cannot conform to the bore shape. All these effects are discussed below.

The axial velocity of the ring is very important because this is the means by which lubricant is entrained. For most of the engine cycle, the ring will move at the velocity of the piston because of its contact with one of the faces of the groove in which it sits. If the ring moves axially in its groove, then its velocity will differ from the piston's velocity. Measurements of ring motion (7) show that the top ring sits on the bottom face of the groove during all of the compression and power strokes, and part of the exhaust stroke, and only moves to the top face during the second half of the exhaust stroke. It stays on the top of the groove during most of the intake stroke, returning to the bottom face near bottom dead-centre (BDC). It would appear, therefore, that the axial velocity of the ring can be assumed to be the same as that of the piston. The radial velocity of the ring is influenced most by the secondary motion of the piston. This movement can produce squeeze-film effects that could have significant effects on the load-carrying capacity of the ring around Top Dead Centre (TDC) (8). Evidence of ring lateral movement was obtained by Garcia et al (9).

The shape of the ring remains fixed, but the angle it subtends to the cylinder wall can change during operation. Firstly, the piston can rotate about the piston pin; secondly, the ring can tilt in its groove so that part of its circumference touches the top face of the groove with the remainder resting on the lower face; and thirdly, the forces on the ring can produce a twist about the cross-sectional axis. Taylor and Evans (7) have measured the first two effects, and Garcia-Atance et al (9) have observed the overall result. If the ring shape is not uniform, then ring rotation can also have an influence.

The load on the ring comes from two sources: the ring tension, and the gas pressure on its rear face. The former remains constant throughout the engine's life, but the latter varies throughout each cycle. If all or part of the ring sits on the lower face of the groove, its rear face is exposed to the pressure in the combustion chamber. In the light of the ring's positioning in its groove, it will be pushed outwards during the high pressure periods of the compression and power strokes. Whilst one would expect higher loads to produce smaller film thicknesses, Moore (10), Mattson (9), Tamminen (10) and Sochting and Sherrington (11) demonstrated that the opposite can occur sometimes. This may be due to the higher temperatures at the higher loads reducing the effective viscosity of the lubricant and thus increasing the oil availability.

One would expect lubricants with higher viscosities to generate higher film thicknesses. However, the amount of oil available to the ring will also have an influence. The oil that lubricates the ring lies on the cylinder wall ahead of it, and its thickness will play a part in determining the degree of starvation in the inlet region of the contact. The depth of the film ahead of the ring will depend on the amount left behind either by the ring itself (after a downstroke) or by the scraper ring which precedes the top ring on a downstroke, and/ or the amount of supplementary lubricant that gets on to the liner via other routes. 
Considering the latter, it is generally accepted that some lubricant must make its way to the top ring via this path, either in mist or liquid form. Gamble et al (12) suggest that the amount of oil transported as a mist is small and can be neglected. If the lubricant travels through the ring gap as a liquid, then one would expect more lubricant to reach the ring if its viscosity was lowered by the higher groove temperatures pertaining at higher loads. It is, as yet, unclear how much oil reaches the contact in this manner, and by how much the hotter lubricant reduces the effective viscosity in the conjunction

Given the wide range of factors influencing film thickness, and the findings of our review of theoretical and experimental work, the authors set out to assess the performance of a widely used commercial modelling package - AVL Excite: Piston and Rings - in terms of how well its predictions compared with one specific set of experimental measurements made in our laboratory.

a) Minimum film thickness

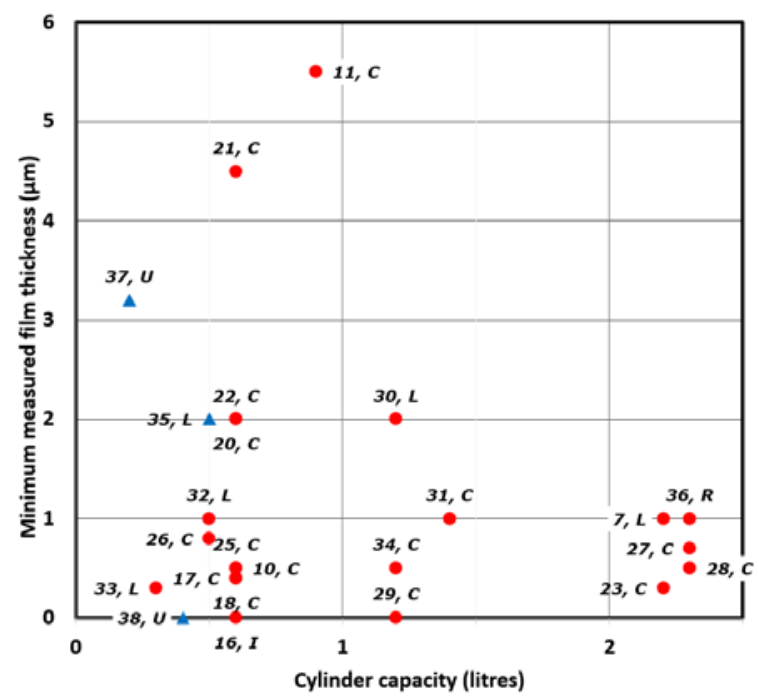

b) Maximum film thickness

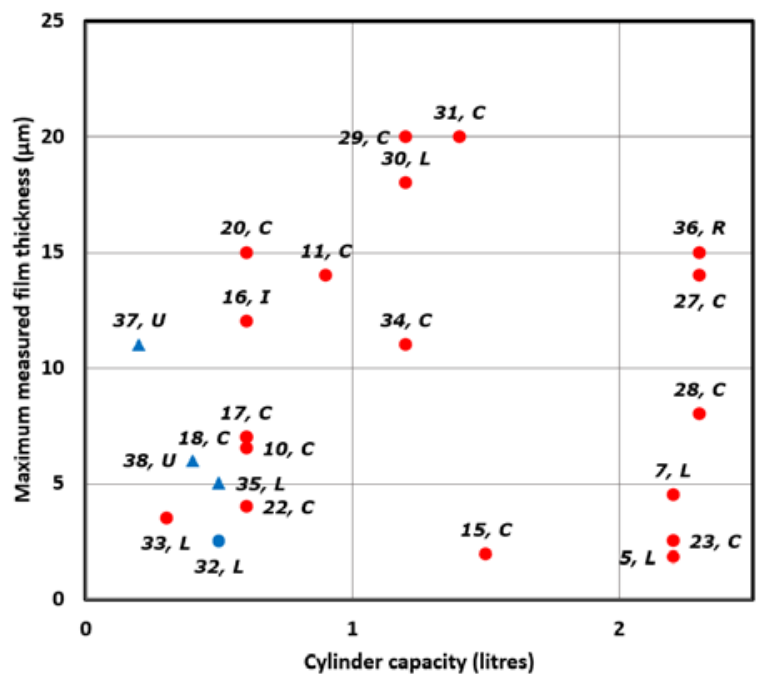

Figure 1 Experimental measurements of compression ring film thickness. $(\mathrm{C}=$ capacitance, I = Inductance, L = Laser Induced Fluorescence, E=Eddy Current, $\mathrm{R}=$ Resistance, $\mathrm{U}=$ Ultra-sound. Numbers against points are reference numbers. Circles are diesel engines; triangles are petrol engines). 
a) Minimum film thickness

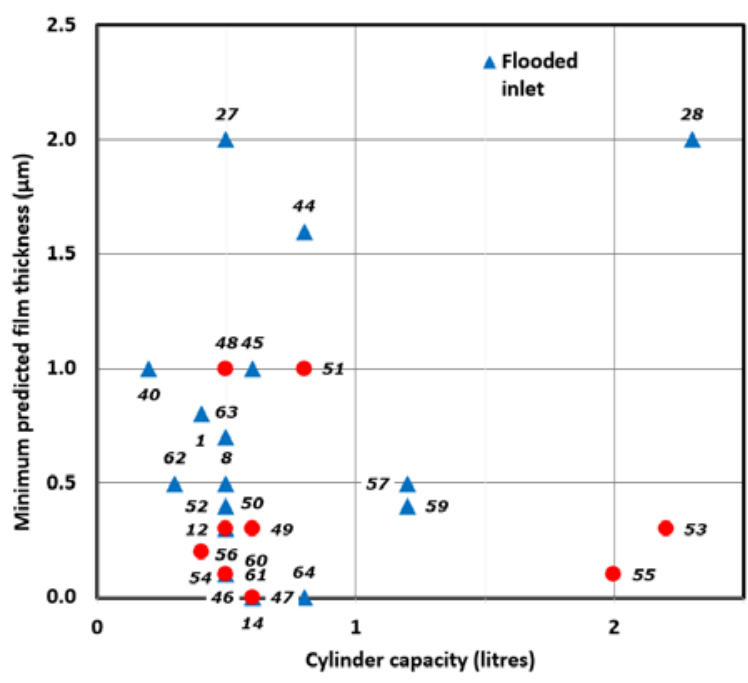

b) Maximum film thickness

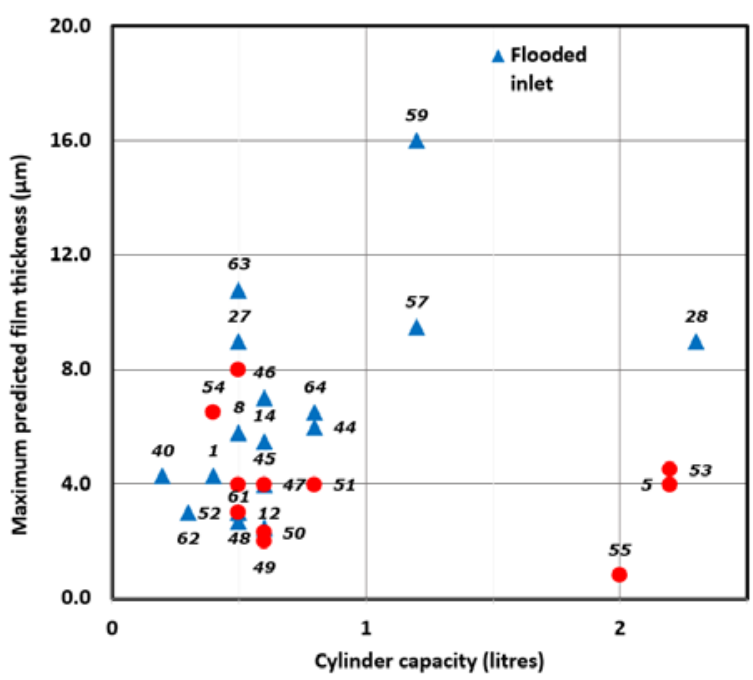

Figure 2 Theoretical predictions of compression ring film thickness. Numbers against points are reference numbers. Circles are starved inlet; triangles are flooded inlet.

\section{The Experimental Apparatus}

Experimental data was collected using a Ford Duratec 1.6 litre gasoline engine which was configured in Formula Ford mode, with a competition camshaft and exhaust, but no dry sump. The engine was modified to take 10 capacitance transducers to measure oft, four thermocouples to measure cylinder temperatures, and a pressure transducer to record cylinder pressure. An outline drawing of the arrangement is presented in Figure 3, and the specification of the engine is listed in Table 1. One thermocouple was attached to the outside wall of the cylinder within the water jacket, with the remaining three devices mounted in the cylinder wall, $1.5 \mathrm{~mm}$ below the liner surface at the following locations just above sensor 1 ('top'), between sensors 5 and 6 ('middle'), and just below sensor 10 ('bottom').

The capacitance transducers were mounted to be nominally flush with the surface of the cylinder wall on the thrust side. The transducers were designed and manufactured by one of the authors; the associated frequency-modulated (FM) system was manufactured by Fylde Electronics Ltd. Details of the calibration system, and a rigorous study of the uncertainty in the measurements is presented below. 


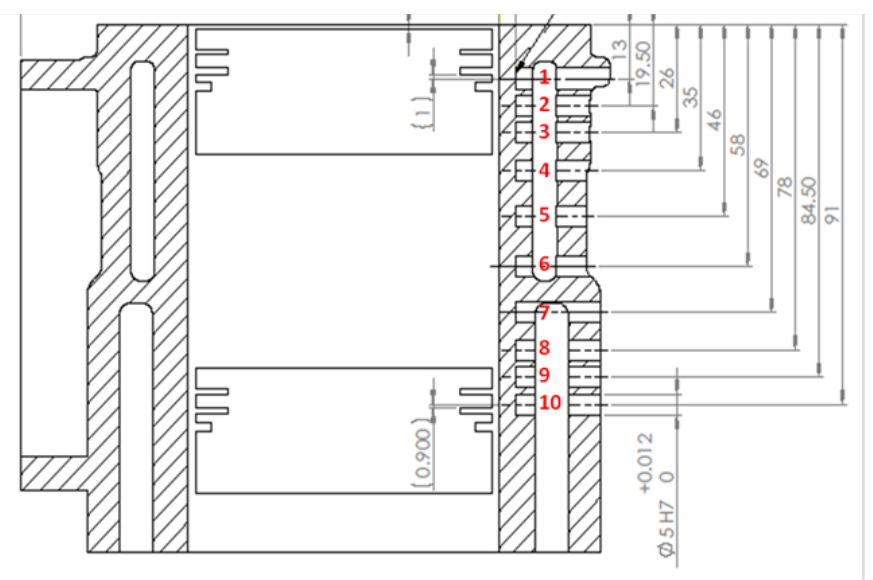

Figure 3 Cylinder schematic showing the transducer locations (mm). 


\begin{tabular}{|l|l|}
\hline Engine & Ford Duratec, DOHC \\
\hline Nominal bore & $79 \mathrm{~mm}$ \\
\hline Stroke & $81.4 \mathrm{~mm}$ \\
\hline Nominal capacity & 1.6 litres \\
\hline Injection Electronic & Multipoint \\
\hline Aspiration & Natural \\
\hline Compression ring face height & $0.90 \mathrm{~mm}$ \\
\hline Height & $1.20 \mathrm{~mm}$ \\
\hline Type & Barrel faced, symmetric \\
\hline Scraper ring face height & $1.12 \mathrm{~mm}$ \\
\hline Type & Napier with grooved face \\
\hline Oil-control ring face height A & $0.40 \mathrm{~mm}$ \\
\hline Oil-control ring face height B & $0.40 \mathrm{~mm}$ \\
\hline Type 3-piece with expander & \\
\hline Liner roughness & Ra.0.87 $\mu \mathrm{m}$ \\
\hline & Rp.2.26 $\mu \mathrm{m}$ \\
\hline & Rv.2.68 $\mu \mathrm{m}$ \\
\hline & Rsk. 0.45 \\
\hline Oil A & SAE $15 \mathrm{~W} / 40$ \\
\hline Oil B & SAE $20 \mathrm{~W} / 50$ \\
\hline Maximum load for the engine & $150 \mathrm{Nm}$ \\
\hline Experimental loads & $40,70 \mathrm{and} 100 \mathrm{~N} \mathrm{~m}$ \\
\hline Experimental speeds & 2000 and $3000 \mathrm{rpm}$ \\
\hline
\end{tabular}

Table 1 Engine details

\section{Calibration and Measurement Accuracy}

In previous work $(9,13,14)$, the authors have measured film thicknesses in a range of engines with a capacitance technique. The technology employed limited most studies to relatively low piston velocities. Recent developments have enabled us to measure film thicknesses with a frequency-modulated (FM) system that can be used at high passing speeds. Detailed investigation has revealed uncertainty in the measurements from the following factors:

a) The calibration of the transducer.

b) Smearing of the face of the electrode during honing in the cylinder.

c) The waviness of the electrodes' surfaces.

d) The depth by which the electrode sits below the liner surface.

e) We examine each of these effects in turn below.

\section{Calibration errors}

Calibration of the sensors in-situ was found to be not possible because the FM system only responds to a moving target. Therefore, calibration in a laboratory-based test apparatus was necessary. It was assumed that all the transducers manufactured would have the same characteristics, and therefore only one of them was calibrated. A single transducer was mounted in a flat plate, which was then ground to a high finish so that the 
transducer was flush with the plate. A metal sphere target, representing the piston ring, was oscillated in a triangular waveform close to the sensor by a piezo-electric actuation system, and the output voltage from the FM system was recorded. Before this could be accomplished, it was necessary to accurately position the target at its nearest point to the sensor, and this was achieved by energising the transducer in amplitude modulated (AM) mode (which can operate with a stationary target). The AM mode was calibrated by placing thin polymer films over the sensor, as shown in Figure 4. Thin aluminium foil was placed on top of the polymer to act as the target, and the two films were pressed against the central electrode by a rubber body. The polymer films varied in thickness from 2.5 to $13 \mu \mathrm{m}$, and were made from Polyethylene Terephthalate (PET) or Polyimide (PI), their thicknesses being confirmed in a white light interferometer. The relative permittivity of lubricating oil is 2.2, whereas the relative permittivities of PET and PI are 3 and 3.4, respectively.

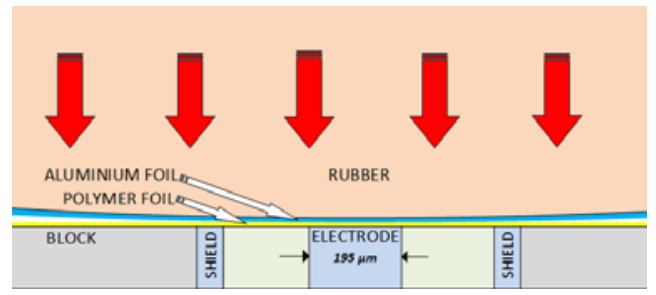

Figure 4 Calibration method of AM with polymer foils.

The voltage output from the calibration could be corrected for the differing permittivities, so that a calibration curve of voltage vs oil-film thickness could be constructed. This was achieved as follows.

The capacitance, $C$, of a sensor is given by Equation 1

$$
C=\varepsilon_{r} \varepsilon_{0} \frac{A}{d}
$$

Equation 1

where $\varepsilon_{r}$ is the relative permittivity, $\varepsilon_{0}$ is the vacuum permittivity, $A$ is the area of the sensor and $d$ is the distance between the face of the sensor and the ring. Figure 5 presents the calibration curve for the transducer energised by the AM system. It is interesting to note that the voltage/oil-film-thickness curve of Fig. 5 is non-linear, particularly below $15 \mu \mathrm{m}$, this feature improves measurement resolution at small film thickness in contrast to the AM system in which resolution remains roughly constant over the measurement range. 


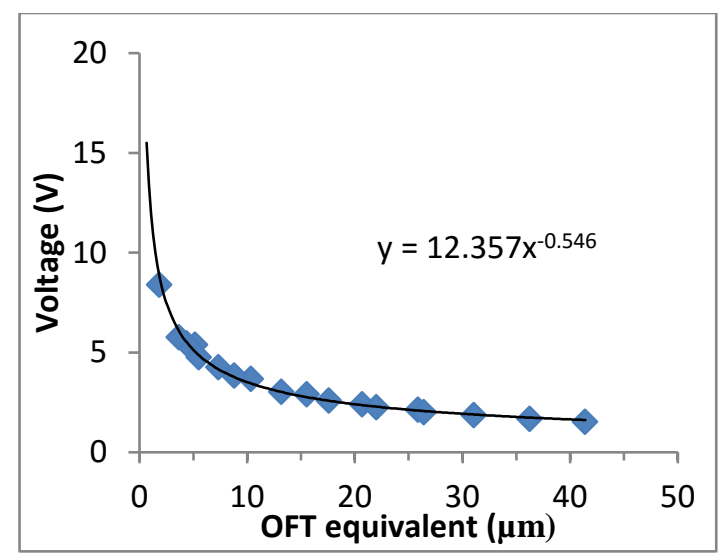

Figure 5 Calibration curve for the AM system

With the transducer energised in AM mode, the target surface of the steel sphere was positioned at a known distance from the sensor (using the data of Figure 5). The target was then oscillated by an amplitude determined by the electro-mechanical properties of the piezo-electric actuation system. The peak-to-peak displacement of the target, as measured by the transducer, was then compared with that predicted from the piezoelectric transducer's characteristics. It was assumed that the piezo system was considerably more accurate than the capacitance system, and thus the latter's precision could be measured against the former. This showed that the AM system had a standard error, $\sigma_{A M}$, of $0.21 \mu \mathrm{m}$, which confirmed the accuracy of the polymer-based calibration approach. Finally, the transducer was excited in frequency modulated (FM) mode, the target oscillated as before, and a final calibration curve produced, as show in Figure 6.

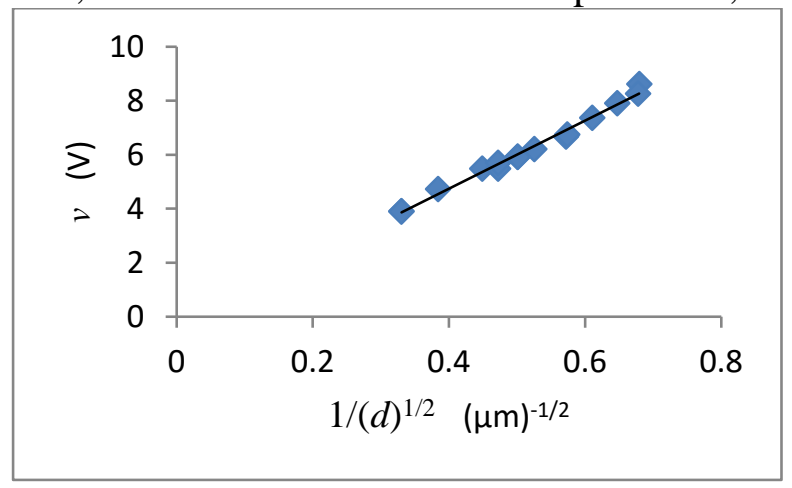

Figure 6 Experimental response of the FM system

Note the abscissa in this figure is the reciprocal of the square-root of oil-film thickness. Thus the calibration line in Figure 6 could be expressed as:

$$
v=k \frac{1}{d^{0.5}}-c
$$

Equation 2

Where $v$ is the output voltage, $d$ is the distance between sensor and target, and $k$ and $c$ are calibration constants.

The process was repeated for the other three channels of the FM system (using the same transducer) and the calibration Table 2 produced. 


\begin{tabular}{|l|l|l|l|l|}
\hline & Channel 0 & Channel 1 & Channel 2 & Channel 3 \\
\hline$k\left(\mathrm{~V} \mu \mathrm{m}^{-0.5}\right)$ & 12.608 & 13.213 & 9.5064 & 8.9993 \\
\hline$c(\mathrm{~V})$ & 0.2996 & 0.3940 & 0.3464 & 0.2766 \\
\hline
\end{tabular}

Table 2 Calibration constants for the FM system

In order to assess the quality of the calibration, the propagation of uncertainty theory has been used to evaluate the standard deviation of the FM system. From the experimental values in Figure 6, it is possible to estimate the standard deviation, $\sigma_{k}$, of the slope of the line and the standard deviation, $\sigma_{c}$ of the intersection with the axis. In addition, the uncertainty from the AM calibration propagates into the FM calibration. Combining these effects we can arrive at an estimate of the standard deviation for the oil film thickness measurements. This standard deviation value depends on the actual value of the measurement and this is shown in Table 3 where the channel with greater standard deviation is presented.

\begin{tabular}{|c|c|c|}
\hline$d(\mu \mathrm{m})$ & $\begin{array}{c}\sigma_{d} \\
(\mu \mathrm{m})\end{array}$ & $\sigma_{d} / d$ \\
\hline 10.0 & $<1.69$ & $<17 \%$ \\
\hline 7.0 & $<1.08$ & $<15 \%$ \\
\hline 5.0 & $<0.73$ & $<15 \%$ \\
\hline 3.0 & $<0.43$ & $<14 \%$ \\
\hline 2.0 & $<0.32$ & $<16 \%$ \\
\hline
\end{tabular}

Table 3 Calibration errors of distance electrode to target.

As shown in Table 3 the standard deviation for a measurement of $2 \mu \mathrm{m}$ is around 0.32 $\mu \mathrm{m}$, while for a measurement of $10 \mu \mathrm{m}$ the standard deviation is around $1.69 \mu \mathrm{m}$. The standard deviation is around $15 \%$ of the actual distance to the electrode for most measurements.

\section{Smearing}

Once the sensors were installed in the engine, they were aligned with the liner surface by a final honing process. Microscope observation revealed this process could cause the material of the electrode to be smeared, thus increasing the area of the electrode and the subsequent capacitance measured at a fixed film thickness. 


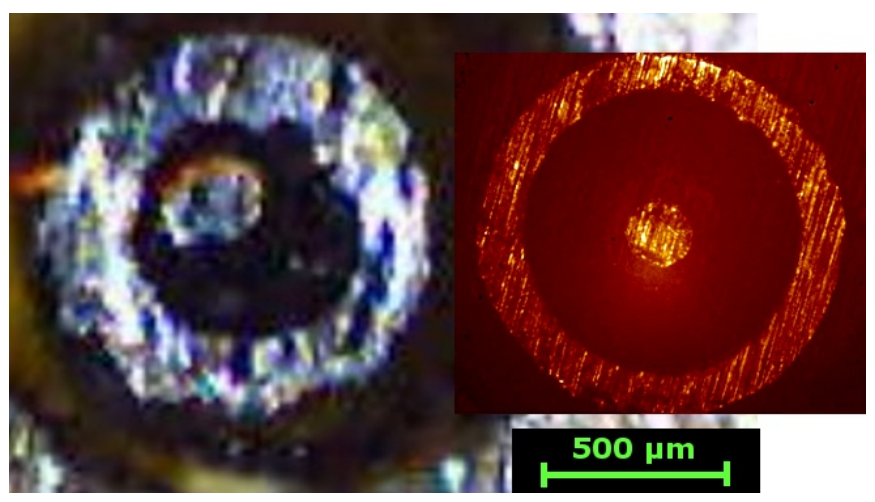

Figure 7 Comparison of electrode area in liner (left) and in the calibration block (right).

Figure 7 compares the surface of sensor 1 in the engine (on the left) with the sensor in the calibration block (on the right). It can be seen that both the electrode (in the centre) and the outer shielding are slightly smeared after honing. The increased area of the shielding would not alter the output voltage from the transducer, but the smearing of the electrode does. The areas of all the sensors in the liner, were, therefore, measured individually by counting the number of pixels in the images of electrode photographs, and it was found that their areas had increased by between $31 \%$ and $89 \%$. The effect of this increment in the area was taken into account according to:

$$
d=\frac{k_{i}{ }^{2}}{\left(v+c_{i}\right)^{2}} \frac{A_{j \text { liner }}}{A_{\text {block }}}
$$

Equation 3

Where $d$ was the distance of the electrode to the target, $k_{i}$ and $c_{i}$ were the calibration constants for channel $i, v$ was the voltage output of the "FM" system, $A_{j}$ liner was the actual electrode area of sensor $j$ in the liner, and $A_{\text {block }}$ was the electrode area in the calibration block. The ratio of areas in equation 3 is added because the capacitance is a function of sensing area over distance, as illustrated in equation 1.

\section{Roughness of the electrode}

Figure 8 and Figure 9 show 3-D surface profiles for sensors 1 and 4, obtained from profilometer scans of surface replicas, along with cross-sectional plots taken by averaging three profiles. Note that the vertical scales in the profile charts are magnified greatly. The two circular grooves visible in each 3-d figure are due to the breakage of a ceramic insulator during honing. The cross-sectional profiles show the degree to which the insulator was fractured and the electrode was roughened. If the distance between the electrode and the ring was the same order as this roughness, then the electrode could no longer be assumed flat, and a suitable correction would have to be applied. Other researchers (15) did a general analysis of this effect for a dimensionless parameter of the waviness respect to the oil film thickness. A simplification to this study was to assume that one of the electrodes forming the capacitance, either the sensor or the target, was flat and the other one had a sinusoidal waviness. Because the capacitance is proportional to the inverse of the distance, the contribution of the peaks close to the surface is more significant than the valleys away from the surface, and this effect is more important the closer the two surfaces are. 

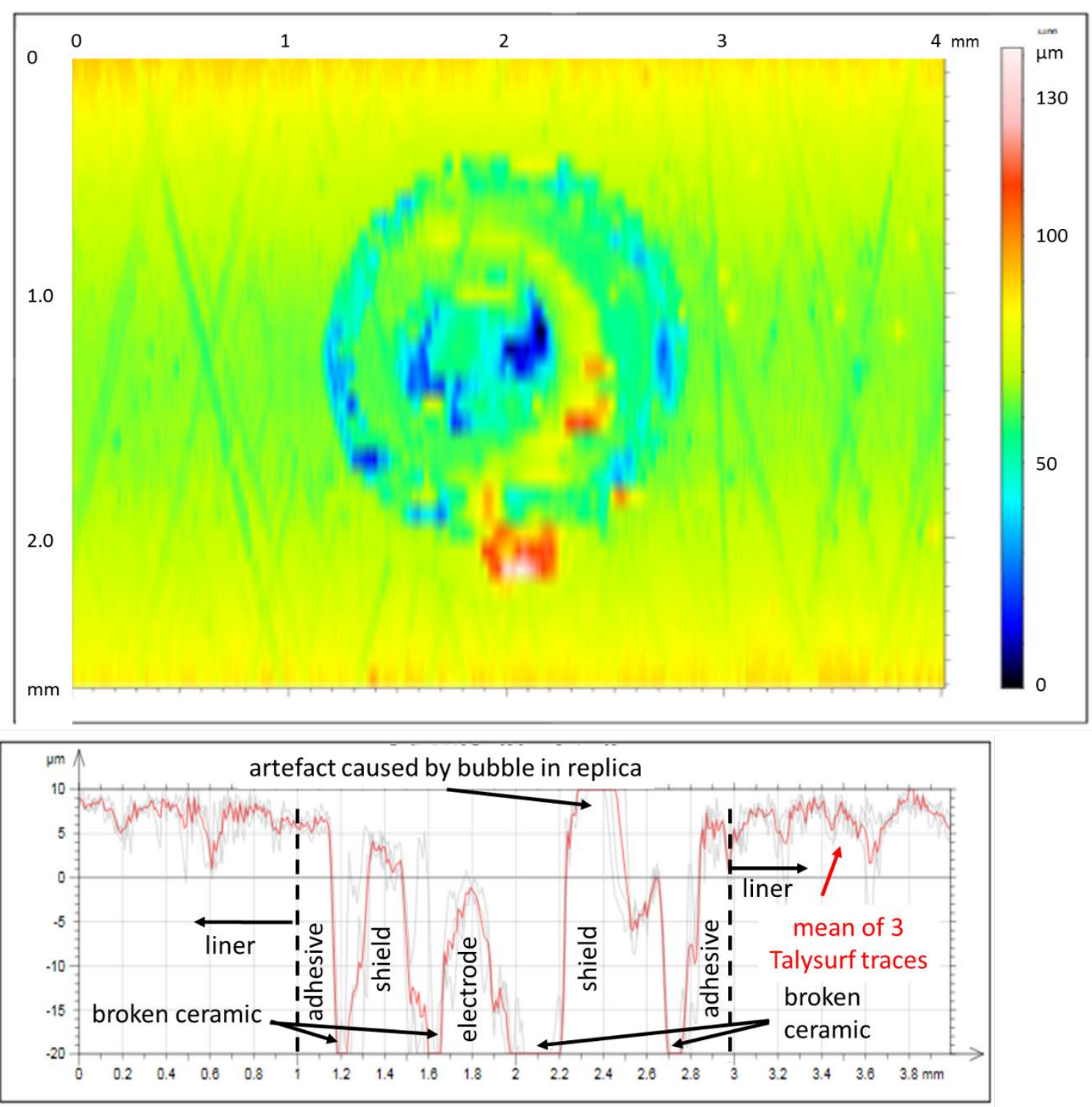

Figure 8 3D surface profile of sensor 1. There are two circle shaped grooves that correspond with the two ceramic materials. Three profiles of the region of the electrode (in light grey) and an averaged profile (in dark red). The electrode was recessed around 9 $\mu \mathrm{m}$ from the mean liner surface. 


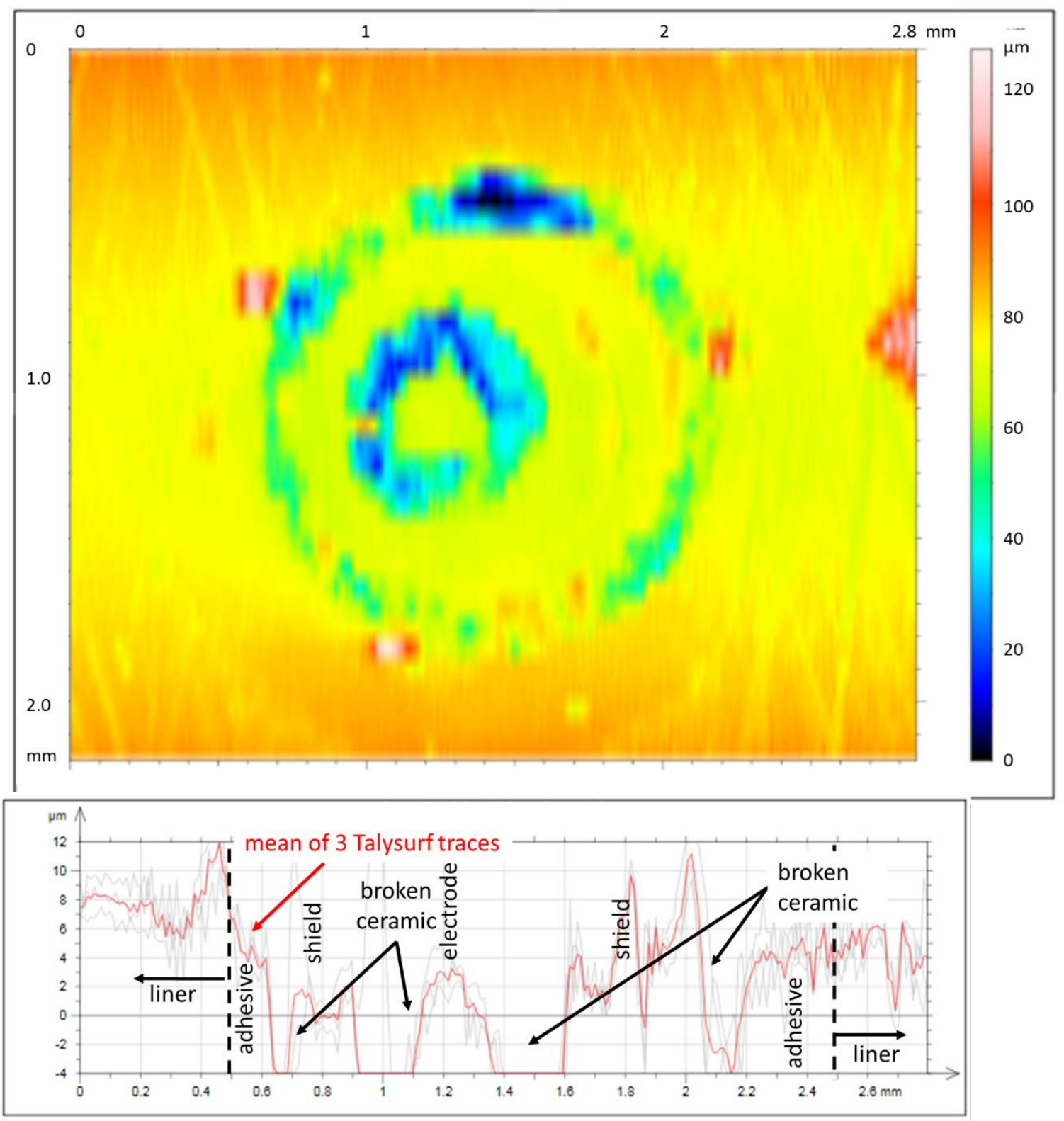

Figure 9 3D surface profile of sensor 4 . There are two circle shaped grooves that correspond with the two ceramic materials. Three profiles of the region of the electrode (in light grey) and an averaged profile (in dark red). The electrode was recessed around 2 $\mu \mathrm{m}$ from the mean liner surface.

Using a simplified version of the model presented in ref (15) Figure 10 shows the scale of the effect for 4 different roughnesses of the sensor. The figure can be interpreted as follows: if the mean surface distance between the ring and the electrode is (say) $5 \mu \mathrm{m}$, and the roughness of the electrode is (say) $R_{a}=2.54, R_{p}=4$, then the transducer will detect that the ring is $3 \mu \mathrm{m}$ away from the electrode, i.e. it will underestimate the oil-film thickness by $2 \mu \mathrm{m}$. 


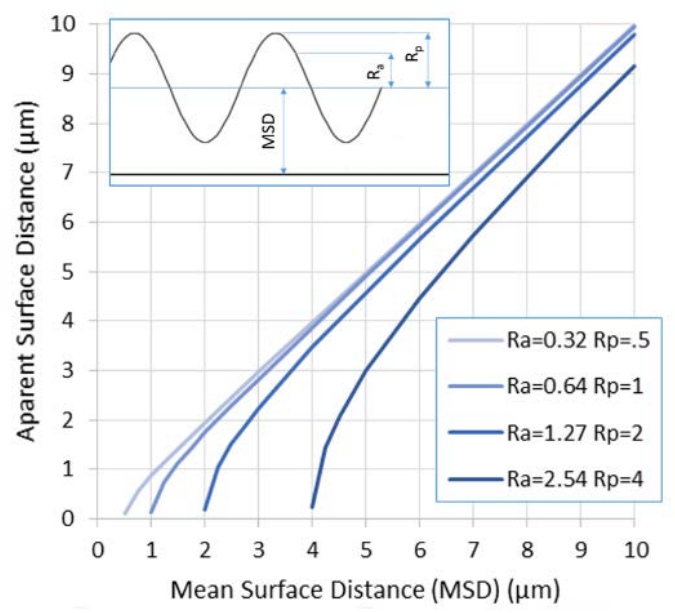

Figure 10 Effect of surface roughness in the measurement of the surface distance with capacitance.

\section{Recess Depth}

As can be seen in Figure 8 and Figure 9, the electrode can be recessed below the liner surface by several micrometres due to the effects of honing. The depth of the recess was estimated by determining the distance between mean lines drawn through both the liner and electrode surfaces. This value was then subtracted from the measured oil-film thickness values as an 'offset'.

\section{Summary}

A number of effects and sources of error have been considered to obtain accurate measurements. The magnitudes of these effects are illustrated in Table 4, where data from 6 transducers (S1 to S4, S7 and S9) are presented during the Power stroke of the engine. Row 2 presents the distances measured between the electrodes and the ring based on the output voltages and the calibration data in Table 2. The next two rows contain adjustments to be made to the data in row 2 because of the amount by which the electrodes were recessed below the surface and the roughness of the electrodes' surfaces. The final corrected film thicknesses are listed in row 5 along with the 95\% confidence intervals in the last row. It can be seen that the sensors with the deepest recesses (S1, S3 and S4) have the largest confidence intervals, and this issue will be discussed further later in the paper.

POWER STROKE (values in $\mu \mathrm{m}$ )

\begin{tabular}{|c|c|c|c|c|c|c|c|}
\hline & Sensor & S1 & S2 & S3 & S4 & S7 & S9 \\
\hline & Distance to electrode (measured) & 9.1 & 1.5 & 9.4 & 10.2 & 2.8 & 2.5 \\
\hline & Offset due to recess (to be subtracted) & 9 & 1.5 & 5.3 & 3.5 & 2.5 & 2 \\
\hline & Roughness effect (to be added) & 1 & 2.8 & 0.3 & 0.4 & 3 & 3 \\
\hline & Estimated film thickness (measured) & 1.1 & 2.8 & 4.5 & 7.1 & 3.3 & 3.6 \\
\hline & $95 \%$ Confidence Interval $( \pm 2 \sigma)$ & \pm 3.1 & \pm 0.5 & \pm 3.2 & \pm 3.5 & \pm 0.8 & \pm 0.8 \\
\hline
\end{tabular}

Table 4 Experimental measurements, application of uncertainties. 


\section{Results and discussion}

The engine was operated at $2000 \mathrm{rpm}$ and $3000 \mathrm{rpm}$, with loads of $40 \mathrm{Nm}, 70 \mathrm{Nm}$ and $100 \mathrm{Nm}$ applied (i.e. $27 \%$, 47\% and 67\% full load), using the SAE $15 \mathrm{~W} / 40$ oil. Tests with the SAE 20W/50 oil were conducted at $2000 \mathrm{rpm}$ and $70 \mathrm{Nm}$, while at $3000 \mathrm{rpm}$ the loads were $40 \mathrm{Nm}, 70 \mathrm{Nm}$ and $100 \mathrm{Nm}$. Liner temperatures were based on linear extrapolation of the readings from the thermocouples, and the estimated values are shown in Table 5. Details of the lubricants' viscosities are listed in Table 6.

\begin{tabular}{|r|r|r|r|r|r|r|}
\hline \multicolumn{9}{|c|}{ SAE 15W/40 } \\
\hline & $40 \mathrm{Nm}$ & $70 \mathrm{Nm}$ & $100 \mathrm{Nm}$ & $40 \mathrm{Nm}$ & $70 \mathrm{Nm}$ & $100 \mathrm{Nm}$ \\
\hline & 77.8 & 78.0 & 84.9 & 78.4 & 81.8 & 85.6 \\
\hline Top & 71.1 & 67.7 & 71.6 & 68.1 & 70.3 & 71.0 \\
\hline Middle & 74.7 & 74.7 & 73.7 & 73.0 & 80.0 & 82.7 \\
\hline Bottom & $70 \mathrm{Nm}$ & $70 \mathrm{Nm}$ & $100 \mathrm{Nm}$ & $40 \mathrm{Nm}$ & $70 \mathrm{Nm}$ & $100 \mathrm{Nm}$ \\
\hline \multicolumn{7}{|c|}{} \\
\hline
\end{tabular}

Table 5 Liner temperatures (C)

\begin{tabular}{|l|c|c|c|c|c|c|}
\hline \multicolumn{7}{|c|}{ SAE 15W40 } \\
\hline & \multicolumn{7}{|c|}{$2000 \mathrm{rpm}$} & \multicolumn{3}{c|}{$3000 \mathrm{rpm}$} \\
\hline & $40 \mathrm{Nm}$ & $70 \mathrm{Nm}$ & $100 \mathrm{Nm}$ & $40 \mathrm{Nm}$ & $70 \mathrm{Nm}$ & $100 \mathrm{Nm}$ \\
\hline Top & 0.0260 & 0.0259 & 0.0205 & 0.0255 & 0.0227 & 0.0200 \\
\hline Middle & 0.0326 & 0.0366 & 0.0321 & 0.0361 & 0.0335 & 0.0327 \\
\hline Bottom & 0.0289 & 0.0289 & 0.0299 & 0.0306 & 0.0242 & 0.0221 \\
\hline \multicolumn{7}{|c|}{ SAE 20W50 } \\
\hline & $40 \mathrm{Nm}$ & $70 \mathrm{Nm}$ & $100 \mathrm{Nm}$ & $40 \mathrm{Nm}$ & $70 \mathrm{Nm}$ & $100 \mathrm{Nm}$ \\
\hline Top & 0.0367 & 0.0289 & 0.0322 & 0.0329 & 0.0336 & 0.0250 \\
\hline Middle & 0.0447 & 0.0414 & 0.0492 & 0.0435 & 0.0464 & 0.0412 \\
\hline Bottom & 0.0433 & 0.0373 & 0.0486 & 0.0367 & 0.0412 & 0.0327 \\
\hline
\end{tabular}

Table 6 Oil Viscosities (Pa-s)

Figure 11 are measurements from these 6 transducers as the compression ring passed over them, for 2 successive engine cycles. The signals recorded during the passage of each ring are substantially noise-free and thus no averaging is necessary, a factor which 
has already been noted in an earlier paper (7). The numbered labels in the first 2 strokes indicate the transducer from which the measurements were obtained. In this figure, the engine was operated at $3000 \mathrm{rpm}$, using the $15 \mathrm{~W} / 40$ lubricant. When data from comparable strokes is examined, good repeatability was observed, with variances of around no more than $1 \mu \mathrm{m}$ being exhibited. Figure 11 compares the measurements with predictions from AVL's EXCITE software for a single engine cycle when the 15W/40 lubricant was employed.
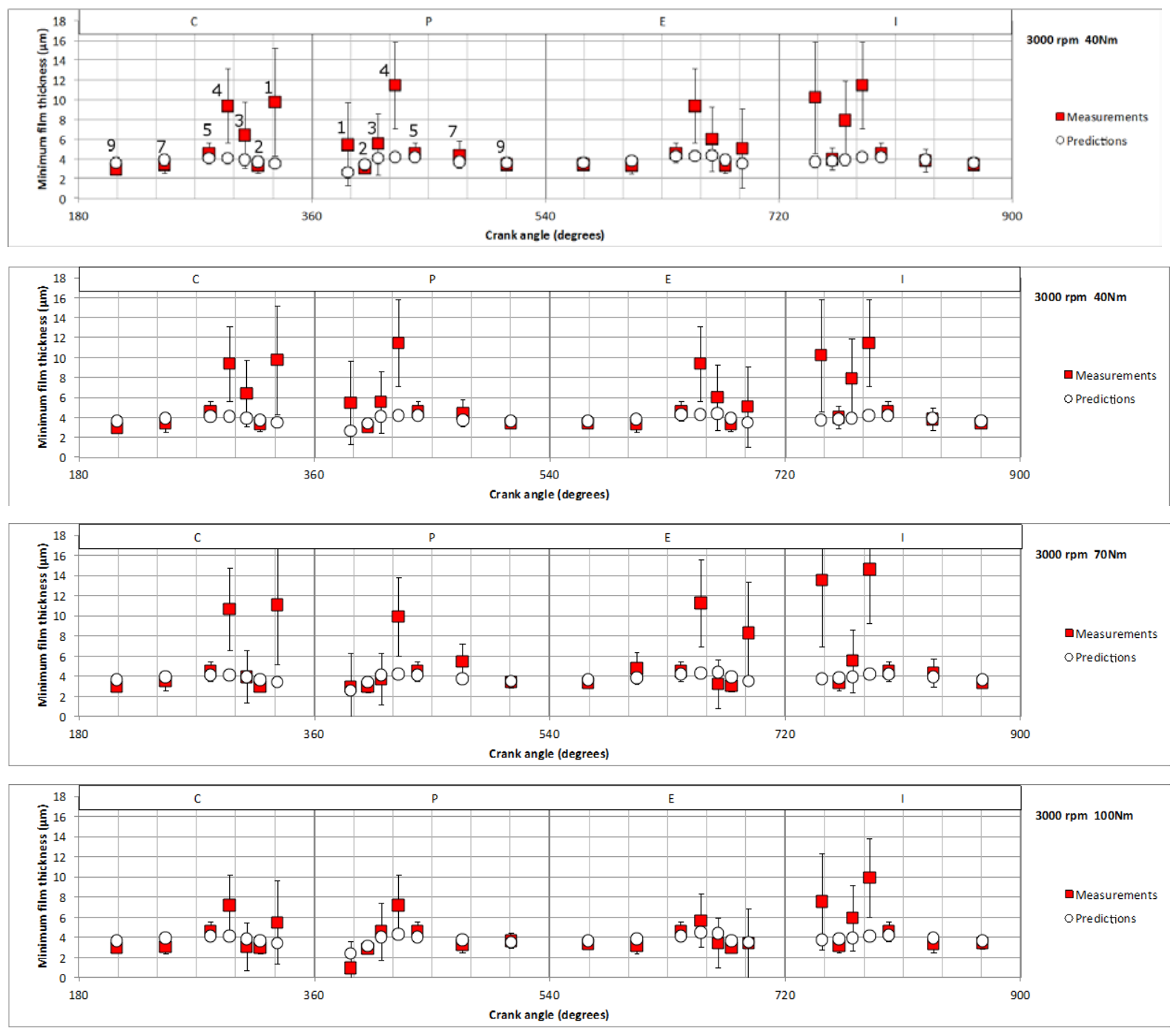

Figure 11. Experimental and theoretical data compared. 3000 rpm, 3 loads,

\section{SAE 15W/ 40 oil. Compression ring.}

Included in the figure are the confidence intervals (one standard deviation) calculated by the method discussed earlier. As discussed, the confidence interval will be large if the distance from the surface of the electrode to the ring is large, which will occur if the actual film thickness is large, or if the electrode is recessed below the liner surface by a 
large amount. The former effect was apparent with transducer 4, and the latter effect was evident with 1 and 3 , where the recess depths were 9 and $5.3 \mu \mathrm{m}$ respectively.

The agreement between the measurements and predictions for sensors 2, 3, 6 and 7 is excellent. There are, however, larger differences between experiment and theory for sensors 1 , and 4 at the lower loads. It would appear, at first glance, that there must be some significant error in the readings from these last two sensors. However, if one examines the data in the last chart (where the load was $100 \mathrm{Nm}$ ), it can be seen that the outputs from sensor 1 are very close to the predicted values in all 4 strokes, suggesting that the sensor was reliable. The discrepancies between predictions and measurements at sensor 4 are reduced in this loading condition, but not by as much as that exhibited by sensor 1. Given this situation, therefore, there is a strong suggestion that at the $40 \mathrm{Nm}$ and $70 \mathrm{Nm}$ load conditions, the ring does not behave in the manner predicted at all locations. In particular, it would appear that near TDC in the compression and induction strokes, the film thicknesses are much greater than predicted. This may be due to the sensor's topography influencing the hydrodynamic lubrication, lubricant availability, outof-roundness in the cylinder, or squeeze effects. This a topic that requires more understanding.

Data obtained at the lower engine speed of $2000 \mathrm{rpm}$ are presented in Figure 12. A similar pattern of behaviour is evident in these experiments, suggesting again that ring behaviour follows theory very well on occasions, but departs from predictions on occasions.
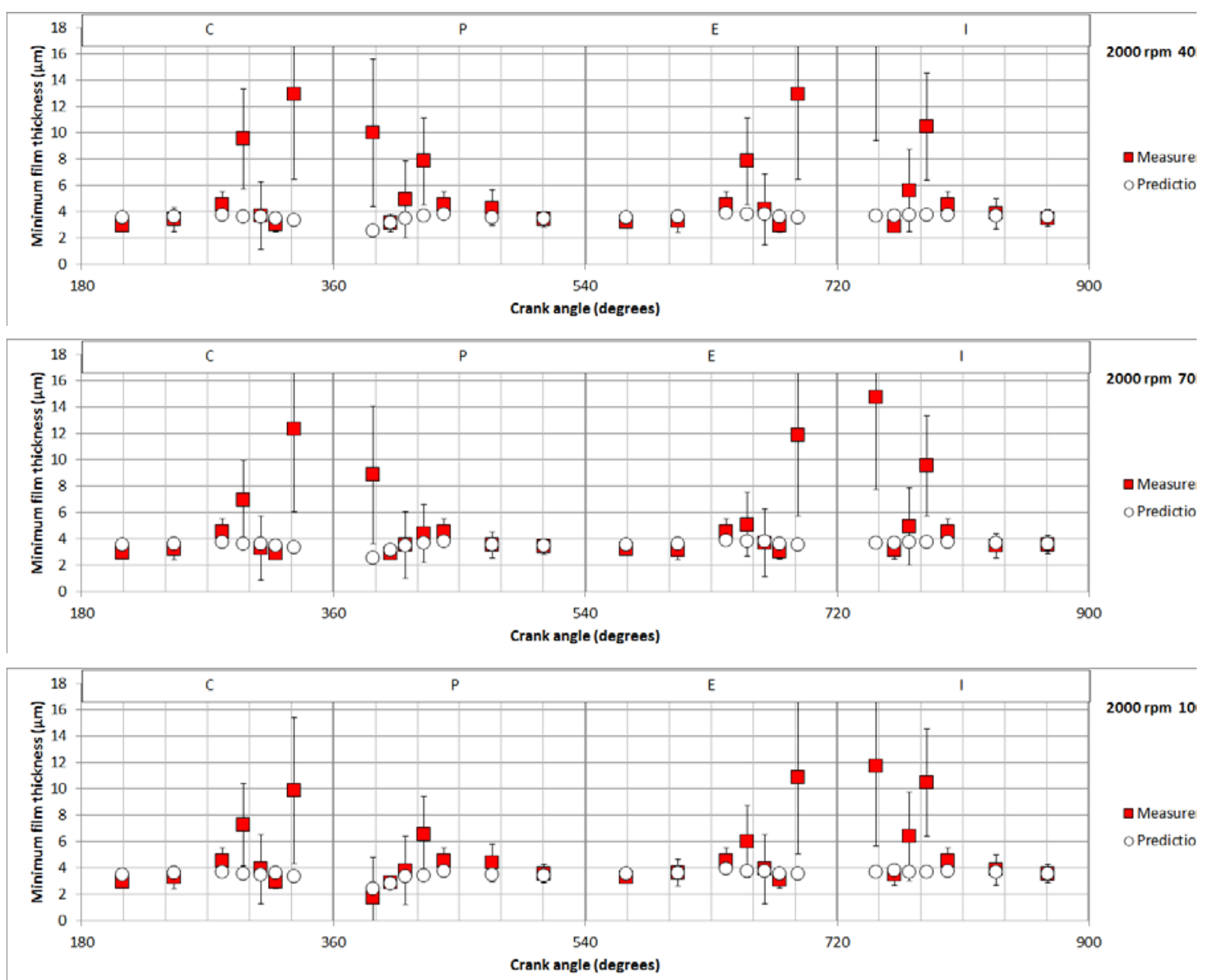
Figure 12 Experimental and theoretical data compared. 2000 rpm, 3 loads, SAE 15W/ 40 oil. Compression ring.

a) $3000 \mathrm{rpm}, \mathbf{1 5 W} / 40$ oil.

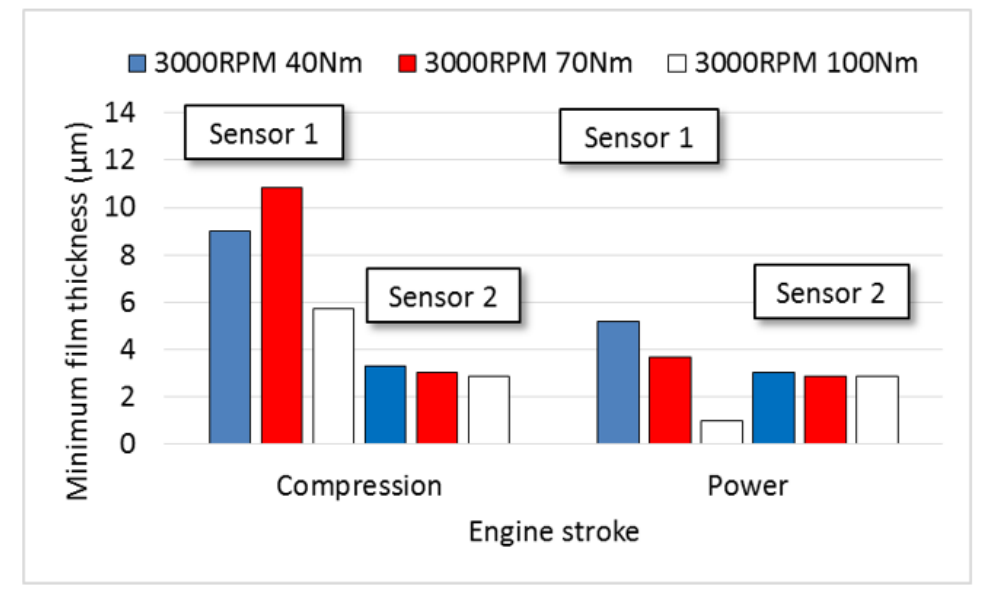

b) $2000 \mathrm{rpm}, 15 \mathrm{~W} / 40$ oil.

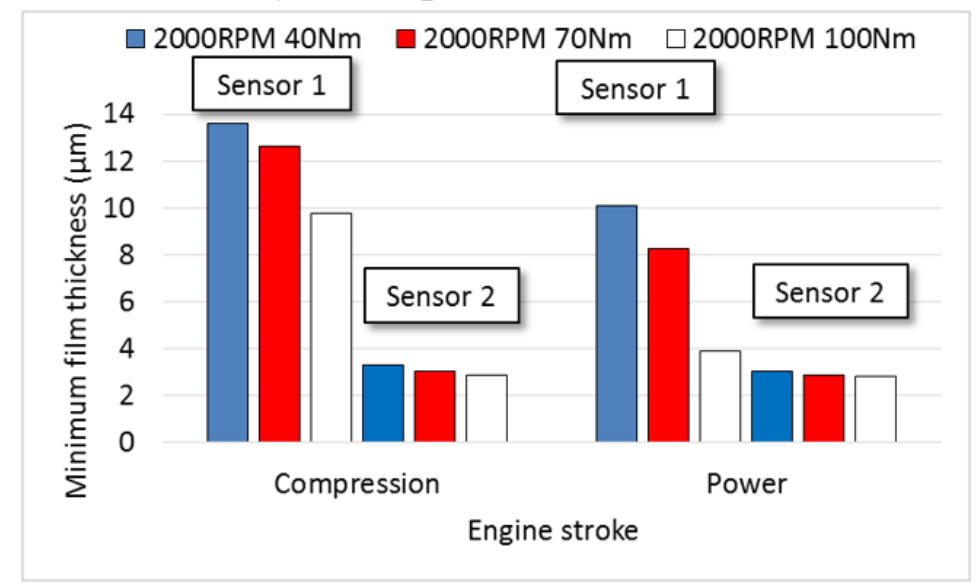

Figure 13. The effects of load and speed on measured minimum film thickness, SAE 15W/40 oil. Compression ring.

In order to examine trends near TDC, the readings obtained in 3 successive cycles have been averaged for sensors 1 and 2, and the results plotted in Figure 13 and Figure 14 for 3 different loads and 2 speeds. In all cases, the film thicknesses measured by sensor 1 dropped as the combustion pressure acted on the back of the ring, the decrease varying between 23\% and 83\%. With the lighter oil (Figure 14), the film thicknesses at sensor 1 on the power stroke were higher at the lower speed. Some of this difference could be explained by the slightly higher viscosities pertaining at the lower speed (see Table 6) but 
it is unlikely that this fully explains the differences in film thickness. Perhaps oil availability and/ or ring lateral motion were also having an effect? Figure 14 also shows that increased power results in reduced film thicknesses at sensor 1 during the power stroke. This is what would be expected given the higher combustion pressures which pertain as the load is increased. Film thicknesses at sensor 2 were little influenced by load or speed, suggesting that differences in combustion pressures were less significant at this crank angle. The effects of oil viscosity on the film thicknesses at sensor 1 are illustrated in Figure 14. The film thicknesses before and after Top Dead Centre Firing (TDCF) show an expected decrease due to the combustion pressure. The film thicknesses in the power stroke varied little with load when the heavier oil was employed, the overall level being higher than the values measured with the less viscous lubricant. It was discussed in the introduction that considerable variations in mid-stroke film thicknesses have been recorded by different research groups. An examination of the data in Figures 11 and 12 indicates that these values are around $3.5 \mu \mathrm{m}$ in all strokes in this engine, and these data agree closely with those predicted.

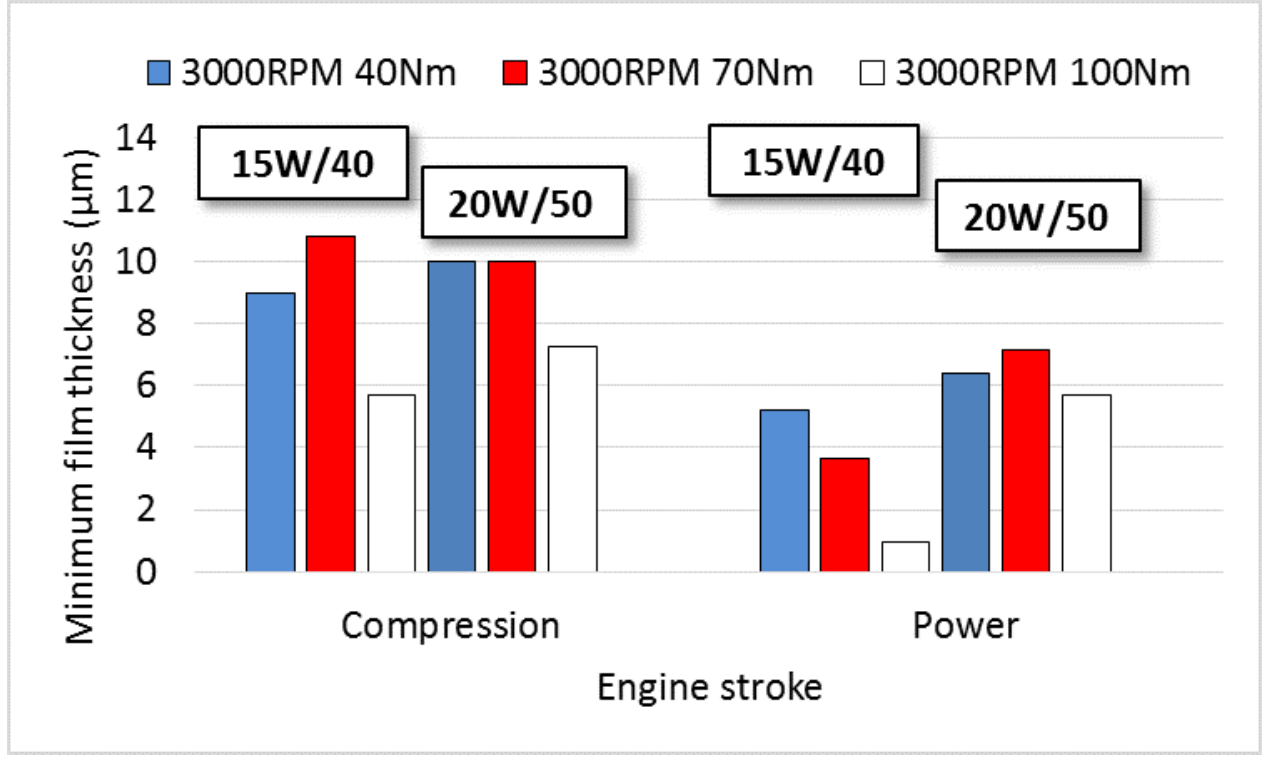

Figure 14. The effects of SAE oil viscosity on minimum film thickness measured at sensor 1. Compression ring.

\section{Conclusions}

A review of the published literature has demonstrated that models of piston-ring lubrication appear to predict minimum film thicknesses which are around the same as those measured. However, predicted and measured maximum film thicknesses are considerably different and may contribute to inaccurate estimates of hydrodynamic power loss. The review identified only 2 papers that compare oil film thickness measurements in firing engines with outputs from sophisticated ring-pack packages, and the agreement between theory and measurement in these cases was not conclusive. 
The calibration of a new design of capacitance-based measurement system has been presented, and a systematic analysis of measurement errors has been reported along with suggestions as to how measurement accuracy could be further improved. Measurements of oil film thickness with standard deviations of $15 \%$ are possible. This can be further improved, by changes in the design and installation of the sensors.

Detailed experimental measurements of film thickness under the top compression ring in a firing petrol engine have been made and are compared with the predictions from a commercial, state-of-the-art, modelling package. The agreement between theory and experiment was excellent in most cases, but some significant differences were observed at the lower load conditions. These differences are as yet unexplained, but may be due to the sensors' topographies influencing the hydrodynamic lubrication, lubricant availability, out-of-roundness in the cylinder, or squeeze effects. This a topic that requires more understanding.

\section{Acknowledgements}

The authors would like to thank AVL Simulation Technologies for financial support and guidance during this project. 


\section{Appendix. Review of experimental and theoretical published data.}

\begin{tabular}{|c|c|c|c|c|c|c|c|c|c|c|c|}
\hline Year & Ref & Authors & $\begin{array}{l}\text { OFT } \\
\text { Min }\end{array}$ & $\begin{array}{l}\text { OFT } \\
\text { Max }\end{array}$ & $\begin{array}{l}\text { Cylinder } \\
\text { size }\end{array}$ & RPM & LOAD & OIL & Temp & $\begin{array}{l}\text { Ring } \\
\text { Pack }\end{array}$ & Sensor \\
\hline 1972 & (16) & Wing, Saunders & 0 & $\begin{array}{l}5 \\
12 *\end{array}$ & 0.6 Diesel & $\begin{array}{l}1330 \\
* 1300\end{array}$ & $\begin{array}{l}6 \text { BHP } \\
{ }_{* 0}\end{array}$ & $\begin{array}{l}\text { Shell Rotella } \\
\text { T30 }\end{array}$ & \begin{tabular}{|l|}
$100-160$ \\
Rings
\end{tabular} & $3 \mathrm{R}$. & Inductance \\
\hline 1974 & (17) & Hamilton, Moore & $\begin{array}{l}0.4- \\
2.5\end{array}$ & 7.0 & 0.6 Diesel & $200-950$ & & & & & Capacitance \\
\hline 1975 & (18) & Hamilton, Moore & 0.5 & 7 & 0.6 Diesel & 1500 & & & 72 & & \\
\hline 1975 & (19) & $\begin{array}{l}\text { Parker, Stafford et } \\
\text { al }\end{array}$ & 0.3 & 19.4 & Perkins & 1000 & & & & & Capacitance \\
\hline 1977 & (20) & Brown, Hamilton & $2 *$ & 15 & 0.6 Diesel & $\begin{array}{l}* 100 \\
400\end{array}$ & & & & & Capacitance \\
\hline 1978 & (21) & Brown, Hamilton & 4.5 & & 0.6 Diesel & 200 & & & & & Capacitance \\
\hline 1978 & (22) & Moore, Hamilton & 2 & 4 & 0.6 Diesel & 1500 & $4.6 \mathrm{BHP}$ & $\begin{array}{l}\text { SAE30 } \\
119.5 c S t \\
(38 C) \\
11.9 c S t(99 C) \\
\end{array}$ & 48 & $4 \mathrm{R}$. & Capacitance \\
\hline 1979 & (23) & Moore & $0.3^{*}$ & 2.5 & 2.2 Diesel & $\begin{array}{l}* 1000 \\
1800\end{array}$ & $\begin{array}{l}* 8.3 \mathrm{BHP} \\
38 \mathrm{BHP}\end{array}$ & & & & Capacitance \\
\hline 1980 & (24) & Moore, Hamilton & $\begin{array}{l}0.2 \\
1.2 * \\
\end{array}$ & & Diesel & \begin{tabular}{|l|}
$1500-$ \\
2250 \\
\end{tabular} & \begin{tabular}{|l|}
$3.3 \mathrm{BHP}$ \\
$* 18 \mathrm{BHP}$ \\
\end{tabular} & & & & Capacitance \\
\hline 1981 & (25) & Moore, Hamilton & \begin{tabular}{|l|}
$0.5-$ \\
2.7
\end{tabular} & & 0.6/? Diesel & 950 & $0.84 \mathrm{BHP}$ & & & & \\
\hline 1981 & (26) & Moore & \begin{tabular}{|l|}
$0.8-$ \\
2.5 \\
\end{tabular} & & 0.5 Diesel & 750 & $3.13 \mathrm{BHP}$ & & & & Capacitance \\
\hline 1983 & (27) & Shin, Tateishi et al. & 0.7 & $\begin{array}{l}14 \\
8^{*}\end{array}$ & 2.3 & 1300 & \begin{tabular}{|l|}
$0 \%$ \\
$* 100 \%$
\end{tabular} & \begin{tabular}{|l} 
SAE30 \\
$10.5 \mathrm{cSt}$
\end{tabular} & $60-120$ & $4 \mathrm{R}$. & $\begin{array}{l}\text { Capacitance on } \\
\text { ring, long sensor }\end{array}$ \\
\hline 1983 & (28) & $\begin{array}{l}\text { Furuhama, Asahi et } \\
\text { al }\end{array}$ & $0.5-3$ & $5-8$ & 2.3 Diesel & $\begin{array}{l}1000- \\
1900 \\
\end{array}$ & $0-100 \%$ & \begin{tabular}{|l|}
$8.5 \mathrm{cst}$ \\
$10.5 \mathrm{cst}$ \\
\end{tabular} & - & $4 \mathrm{R}$. & $\begin{array}{l}\text { Capacitance on } \\
\text { ring, long sensor }\end{array}$ \\
\hline 1985 & (10) & Moore & 0.5 & $\begin{array}{l}2.5 \\
6.5 *\end{array}$ & 0.6 Diesel & 1000 & $\begin{array}{l}0.6 \mathrm{~kW} \\
\text { per Cyl. }\end{array}$ & \begin{tabular}{|l} 
SAE40 \\
SAE5W \\
SAE10W40 \\
\end{tabular} & & $\begin{array}{l}4 \mathrm{R} . \\
* 1 \mathrm{R} .\end{array}$ & Capacitance \\
\hline 1990 & (29) & $\begin{array}{l}\text { Myers, Borman et } \\
\text { al. }\end{array}$ & 0 & 20 & 1.2 Diesel & & & & & $4 \mathrm{R}$. & $\begin{array}{l}\text { Capacitance } \\
\text { TDC }\end{array}$ \\
\hline 1991 & (30) & \begin{tabular}{|l|} 
Richardson, \\
Borman
\end{tabular} & 2 & 18 & 1.2 Diesel & 2000 & & SAE30 & & & $\begin{array}{l}\text { Laser Induced } \\
\text { Fluorescence }\end{array}$ \\
\hline 1995 & $(31)$ & Mattsson & 1 & 20 & 1.4 Diesel & $\begin{array}{l}1000- \\
2000\end{array}$ & $\begin{array}{l}0-80 \mathrm{Nm} \\
\text { per Cyl. }\end{array}$ & - & 80 & $3 \mathrm{R}$. & Capacitance \\
\hline 1995 & (5) & $\begin{array}{l}\text { Taylor, Brown et } \\
\text { al. }\end{array}$ & & 1.8 & $\begin{array}{l}2.2 \text { Diesel } \\
\text { CAT1Y73 }\end{array}$ & $\begin{array}{l}1000- \\
1800\end{array}$ & \begin{tabular}{|l|} 
Low \\
$(20 \mathrm{Nm}$ \\
per \\
cylinder $)$ \\
\end{tabular} & $15 \mathrm{~W} / 40$ & $63-97$ & $\begin{array}{l}4 \\
\text { rings }\end{array}$ & \begin{tabular}{|l} 
Laser Induced \\
Fluorescence
\end{tabular} \\
\hline 2000 & $(32)$ & $\begin{array}{l}\text { Yoshida, } \\
\text { Kobayashi et al. }\end{array}$ & 1 & 2.5 & 0.5 Petrol & 2500 & Full & - & - & $3 \mathrm{R}$. & \begin{tabular}{|l} 
Laser Induced \\
Fluorescence \\
\end{tabular} \\
\hline 2000 & (33) & $\begin{array}{l}\text { Seki, Nakayama et } \\
\text { al. }\end{array}$ & 0.3 & 3.5 & 0.3 Diesel & 2000 & \begin{tabular}{|l|}
$75 \%$ \\
$8 \mathrm{MPa}$ \\
\end{tabular} & SAE 30 & 80 & $3 \mathrm{R}$. & \begin{tabular}{|l|} 
Laser Induced \\
Fluorescence \\
\end{tabular} \\
\hline 2000 & (34) & $\begin{array}{l}\text { Takiguchi, Sasaki } \\
\text { et al. }\end{array}$ & $0.5^{*}$ & $\begin{array}{l}11^{*} \\
9^{*+}\end{array}$ & 1.2 Diesel & $\begin{array}{l}1600- \\
2800\end{array}$ & $\begin{array}{l}\text { No load } \\
{ }^{\dagger} \text { Full }\end{array}$ & 10.87cSt & $100-140$ & $3 \mathrm{R}$. & $\begin{array}{l}\text { Capacitance on } \\
\text { ring, } \\
* \text { It assumes } \\
0.5 \text { um } \\
\end{array}$ \\
\hline 2001 & (15) & $\begin{array}{l}\text { Ducu, Donahue et } \\
\text { al. }\end{array}$ & & 1.93 & 1.5 Diesel & 1300 & $40 \%$ & - & - & - & Capacitance \\
\hline 2003 & (35) & Weimar, Spicher & 2 & 5 & 0.5 Petrol & $\begin{array}{l}800- \\
1500 \\
\end{array}$ & - & - & \begin{tabular}{|l|}
$40-80$ \\
oil
\end{tabular} & $3 \mathrm{R}$. & \begin{tabular}{|l|} 
Laser Induced \\
Fluorescence
\end{tabular} \\
\hline 2004 & (7) & Taylor, Evans & 1 & 4.5 & $\begin{array}{l}\text { 2.2 Diesel } \\
\text { CAT1Y73 }\end{array}$ & $\begin{array}{l}1000- \\
1800\end{array}$ & $\begin{array}{l}20-190 \\
\text { Nm } \\
\text { Per Cyl. }\end{array}$ & $\begin{array}{l}\text { SAE50 } \\
\text { SAE30 } \\
\text { SAE10W }\end{array}$ & $\begin{array}{l}100-200 \\
\text { Pist. }\end{array}$ & 4 R. & \begin{tabular}{|l} 
Laser \\
Induced \\
Fluorescence
\end{tabular} \\
\hline 2006 & (6) & $\begin{array}{l}\text { Tamminen, } \\
\text { Sandström et al }\end{array}$ & 1 & 19 & 8.7 Diesel & 900 & $10-100 \%$ & SAE40 & \begin{tabular}{|l|}
$85-120$ \\
Pist.
\end{tabular} & $3 \mathrm{R}$. & Inductance \\
\hline
\end{tabular}




\begin{tabular}{|c|c|c|c|c|c|c|c|c|c|c|c|}
\hline 2007 & $(36)$ & Saad, Kamo et al. & 1 & \begin{tabular}{|l|}
15 \\
$11^{*}$
\end{tabular} & \begin{tabular}{|l|} 
2.3 Diesel \\
Sing. Cyl.
\end{tabular} & 1400 & \begin{tabular}{|l|}
$56 \mathrm{Nm}$ \\
$* 165 \mathrm{Nm}$
\end{tabular} & $15 \mathrm{w} 40$ & \begin{tabular}{|l|}
1488 \\
93
\end{tabular} & $3 \mathrm{R}$. & $\begin{array}{l}\text { Voltage drop } \\
\text { (resistance) }\end{array}$ \\
\hline 2009 & (11) & \begin{tabular}{|l|} 
Söchting, \\
Sherrington
\end{tabular} & 5.5 & 14 & 0.9 Diesel & 2000 & \begin{tabular}{|l|}
$60-160$ \\
$\mathrm{Nm}$
\end{tabular} & $\begin{array}{l}\text { SAE20 } \\
\text { SAE50 } \\
\text { SAE5W50 }\end{array}$ & $90-115$ & $3 \mathrm{R}$. & Capacitive \\
\hline 2012 & (37) & Mills, Avan et al & 3.2 & $\begin{array}{l}6 \\
11^{*}\end{array}$ & 0.2 Petrol & 2230 & \begin{tabular}{|l|}
$90 \%$ \\
$(7 \mathrm{Nm})$ \\
$*$ Idle
\end{tabular} & $15 w 40$ & $>100$ & $3 \mathrm{R}$. & Ultrasound \\
\hline 2014 & (38) & Mills, Vail et al & 0 & $\begin{array}{l}6 \\
5^{*}\end{array}$ & 0.4 Petrol & 3200 & $\begin{array}{l}25 \mathrm{Nm} \\
* 35 \mathrm{Nm}\end{array}$ & $10 \mathrm{w} 40$ & - & $2 \mathrm{R}$. & $\begin{array}{l}\text { Ultrasound } \\
\text { Deconvoluted }\end{array}$ \\
\hline
\end{tabular}

Table 7 Compilation of published results of experimental measurements. Top compression ring.

\begin{tabular}{|c|c|c|c|c|c|c|c|c|c|c|c|}
\hline Year & Ref & Authors & $\begin{array}{l}\text { OFT } \\
\text { Min }\end{array}$ & $\begin{array}{l}\text { OFT } \\
\text { Max }\end{array}$ & $\begin{array}{l}\text { Cylinder } \\
\text { size }\end{array}$ & RPM & LOAD & OIL & Temp & $\begin{array}{l}\text { Ring } \\
\text { Pack }\end{array}$ & Comment \\
\hline 1959 & (1) & Furuhama & \begin{tabular}{|l|l|}
0.8 \\
$2.3^{*}$ \\
\end{tabular} & \begin{tabular}{|l|l|}
2 \\
$4.3^{*}$ \\
\end{tabular} & 0.4 & \begin{tabular}{|l|}
500 \\
$* 3000$
\end{tabular} & \begin{tabular}{|l|}
$6180 \mathrm{~N} / \mathrm{m}$ \\
Load of R. \\
\end{tabular} & $\begin{array}{l}20.5 \times 10^{-8} \\
\mathrm{Kg} \mathrm{s} / \mathrm{cm}^{2} \\
\end{array}$ & 80 & $1 \mathrm{R}$. & \begin{tabular}{|l|} 
Fully Flooded, \\
Oscillating Cyl. \\
\end{tabular} \\
\hline 1979 & (39) & Ruddy, Dowson et al & & 12 & \begin{tabular}{|l|} 
8.9 Diesel \\
2-Stroke
\end{tabular} & 290 & - & - & - & $3 \mathrm{R}$. & Starved \\
\hline 1979 & (40) & $\begin{array}{l}\text { Rohde, Whitaker et } \\
\text { al }\end{array}$ & 1 & 4.3 & 0.2 No head & 3000 & Motored & $6.89 \times 10^{-3} \mathrm{~Pa} \mathrm{~s}$ & - & $1 \mathrm{R}$. & Fully Flooded \\
\hline 1980 & (41) & Ruddy, Parsons et al & & 11 & - & - & - & - & - & $1 \mathrm{R}$. & $\begin{array}{l}\text { Log scale. No } \\
\text { commented. }\end{array}$ \\
\hline 1980 & (42) & Rohde & & 2.5 & 0.6 & 1400 & \begin{tabular}{|c|}
$0.420 \mathrm{MPa}$ \\
$0.748 \mathrm{MPa}$ \\
BMEP
\end{tabular} & $6.89 \times 10^{-3} \mathrm{~Pa} \mathrm{~s}$ & - & $1 \mathrm{R}$. & \\
\hline 1981 & (43) & $\begin{array}{l}\text { Ruddy, Economou et } \\
\text { al }\end{array}$ & & 15 & - & Medium & - & $\begin{array}{l}\text { SAE } 40 \\
\text { SAE } 50\end{array}$ & - & $4 \mathrm{R}$. & \begin{tabular}{|l|} 
Log scale \\
Fully Flooded
\end{tabular} \\
\hline 1982 & (44) & $\begin{array}{l}\text { Richez, Constans et } \\
\text { al }\end{array}$ & 1.6 & $\begin{array}{l}3.3 \\
6^{*}\end{array}$ & 0.8 Petrol & $\begin{array}{l}800 \\
* 2400 \\
\end{array}$ & Motored & $\begin{array}{l}13 \times 10^{-3} \\
\mathrm{Kg} / \mathrm{m} / \mathrm{s}\end{array}$ & - & $3 \mathrm{R}$. & Fully Flooded \\
\hline 1983 & (28) & $\begin{array}{l}\text { Furuhama, Asahi et } \\
\text { al }\end{array}$ & $2-5$ & 9 & 2.3 Diesel & $\begin{array}{l}1000- \\
1900 \\
\end{array}$ & $0-100 \%$ & $\begin{array}{l}8.5 c s t \\
10.5 c s t \\
\end{array}$ & - & $4 \mathrm{R}$. & Fully Flooded \\
\hline 1983 & (27) & Shin, Tateishi et al & 2 & 9 & 0.5 & 1000 & & & & $4 \mathrm{R}$. & Fully Flooded \\
\hline 1992 & (45) & $\begin{array}{l}\text { Grice, Sherrington et } \\
\text { al }\end{array}$ & 1 & 4 & 0.6 Diesel & $\begin{array}{l}900- \\
1650\end{array}$ & Motored & - & 140 & $4 \mathrm{R}$. & $\begin{array}{l}\text { Fully Flooded, } \\
\text { bore distort. }\end{array}$ \\
\hline 1995 & (14) & Ma, Smith et al & 0 & 5.5 & 0.6 Diesel & 1500 & $5.5 \mathrm{MPa}$ & SAE20 & $\begin{array}{l}150 \\
80\end{array}$ & $4 \mathrm{R}$. & Fully Flooded \\
\hline 1995 & (46) & Ma, Smith et al & 0 & 7 & 0.6 Diesel & 1500 & $5.5 \mathrm{MPa}$ & SAE20 & $\begin{array}{l}150 \\
80 \\
\end{array}$ & $4 \mathrm{R}$. & $\begin{array}{l}\text { Fully Flooded, } \\
\text { ring twist }\end{array}$ \\
\hline 1996 & (47) & Ma, Sherrington et al & 0 & $2-4$ & 0.6 Diesel & 1500 & - & SAE20 & $\begin{array}{l}150 \\
80\end{array}$ & $4 \mathrm{R}$. & Starved \\
\hline 1995 & (5) & Taylor, Brown et al & & 4 & $\begin{array}{l}\text { 2.2 Diesel } \\
\text { CAT1Y73 }\end{array}$ & $\begin{array}{l}1000- \\
1800\end{array}$ & \begin{tabular}{|l} 
Low \\
(20Nm per \\
cylinder)
\end{tabular} & $15 \mathrm{~W} / 40$ & 63-97 & $4 \mathrm{R}$. & Partially \\
\hline 1997 & (48) & $\begin{array}{l}\text { Sanda, Murakami et } \\
\text { al }\end{array}$ & 1 & $\begin{array}{l}3 \\
4 *\end{array}$ & 0.5 & $\begin{array}{l}1000- \\
2000\end{array}$ & \begin{tabular}{|l|} 
Full load \\
$*$ Motored
\end{tabular} & $0.02 \mathrm{~Pa} \mathrm{~s}$ & - & $3 \mathrm{R}$. & Starved \\
\hline 1997 & (49) & Ma, Sherrington et al & 0.3 & 2 & 0.6 & 950 & $3.2 \mathrm{MPa}$ & SAE30 & $\begin{array}{l}150 \\
80\end{array}$ & $3 \mathrm{R}$. & Partially flooded \\
\hline 1997 & (50) & Ma, Smith et al & 0.3 & 2.3 & 0.6 & 950 & 3.2 MPa & SAE30 & $\begin{array}{l}150 \\
80\end{array}$ & $3 \mathrm{R}$. & $\begin{array}{l}\text { Partially flooded } \\
\text { Bore distort. }\end{array}$ \\
\hline 1998 & (51) & Liu, Xie et al & 1 & 4 & 0.8 & 2000 & 3.5MPa & $\begin{array}{l}0.003 \mu \mathrm{m} ? \\
0.008 \mu \mathrm{m} ?\end{array}$ & - & $3 \mathrm{R}$. & $\begin{array}{l}\text { Starved, } \\
(13 \mu \mathrm{m} \text { with } \\
\text { roughness, } \\
\text { inconsistency) }\end{array}$ \\
\hline 2000 & (52) & Sawicki, Yu & 0.4 & 3 & 0.5 & 2000 & - & $0.0069 \mathrm{~Pa} \mathrm{~s}$ & - & $3 \mathrm{R}$. & $\begin{array}{l}\text { Fully flooded, } \\
\text { cavitated }\end{array}$ \\
\hline
\end{tabular}




\begin{tabular}{|c|c|c|c|c|c|c|c|c|c|c|c|}
\hline 2000 & (53) & Priest, Dowson et al & $0.3-0.6$ & 3-4.5 & $\begin{array}{l}2.2 \text { Diesel } \\
\text { CAT1Y73 }\end{array}$ & 1200 & $\begin{array}{l}\text { 1.4 MPa } \\
\text { BMEP }\end{array}$ & $\begin{array}{l}\text { SAE30 4mPas- } \\
\text { 13mPas }\end{array}$ & - & $4 \mathrm{R}$. & $\begin{array}{l}\text { Starved and } \\
\text { cavitated }\end{array}$ \\
\hline 2001 & $(54)$ & $\begin{array}{l}\text { Frølund, Schramm et } \\
\text { al }\end{array}$ & $\begin{array}{l}1.5^{*} \\
0.2\end{array}$ & $\begin{array}{l}6.5^{*} \\
1.5\end{array}$ & 0.4 Petrol & 2500 & $66 \%$ & SAE 10W30 & $\begin{array}{l}{ }^{*} \text { Cold } \\
\text { Warmed }\end{array}$ & $3 \mathrm{R}$. & Starved \\
\hline 2002 & $(55)$ & Tian & 0.1 & 0.8 & 2.0 Diesel & 1200 & $100 \%$ & 10W50 & $137-160$ & $3 \mathrm{R}$. & Partially flooded \\
\hline 2002 & (56) & Piao, Gulwadi & 0.3 & $\begin{array}{l}1.5 \\
3.5^{*} \\
8 \dagger \\
\end{array}$ & 0.5 Petrol & $\begin{array}{l}2000 \\
*+6000\end{array}$ & - & - & - & $3 \mathrm{R}$. & $\begin{array}{l}\text { Partially flooded } \\
\dagger \text { liner ramp and } \\
\text { ring inertia }\end{array}$ \\
\hline 2003 & $(12)$ & Gamble, Priest et al & 0.3 & \begin{tabular}{|l|}
3 \\
$1.7^{*}$
\end{tabular} & 0.5 & 2500 & $\begin{array}{l}0.5 \mathrm{MPa} \\
\text { BMEP }\end{array}$ & SAE30 & - & \begin{tabular}{|l|}
3 \\
Rings \\
\end{tabular} & $\begin{array}{l}\text { Fully } \\
\text { *Partially flooded }\end{array}$ \\
\hline 2003 & (57) & $\begin{array}{l}\text { Harigaya, Suzuki et } \\
\text { al }\end{array}$ & 0.5 & $\begin{array}{l}7.5 \\
8.4^{*} \\
9.5 \dagger\end{array}$ & 1.2 Diesel & $\begin{array}{l}1600 \\
\dagger 2800\end{array}$ & $0 \%$ & SAE30 & $\begin{array}{c}132 \\
* 102 \\
\text { (ring) }\end{array}$ & $1 \mathrm{R}$. & Fully flooded \\
\hline 2005 & (58) & $\begin{array}{l}\text { Bolander, Steenwyk } \\
\text { et al }\end{array}$ & 0 & 6.5 & \begin{tabular}{|l|} 
Rig $\left(60^{\circ}\right.$ \\
Sector) \\
Bore 137.2 \\
Stroke 66.7 \\
\end{tabular} & $30-300$ & $1-8 \mathrm{Kgf}$ & $\begin{array}{l}\text { SAE } 30 \\
0.20 \mathrm{~Pa} \mathrm{~s}\end{array}$ & 20 & $\begin{array}{l}1 \\
\text { Ring }\end{array}$ & $\begin{array}{l}\text { Fully flooded, } \\
\text { Effects of speed, } \\
\text { load }\end{array}$ \\
\hline 2006 & (6) & $\begin{array}{l}\text { Tamminen, } \\
\text { Sandström et al. }\end{array}$ & 0 & 6 & 8.7 Diesel & 900 & & & & $3 \mathrm{R}$. & $\begin{array}{l}\text { Ricardo } \\
\text { RINGPAK } 4.2\end{array}$ \\
\hline 2006 & (59) & $\begin{array}{l}\text { Harigaya, Suzuki et } \\
\text { al }\end{array}$ & $\begin{array}{l}0.4 \\
0.47 \dagger \\
2 *\end{array}$ & $\begin{array}{l}5.5 \\
7.3 \dagger \\
16^{*}\end{array}$ & 1.2 Diesel & $\begin{array}{l}1600 \\
\dagger 1600 \\
* 800\end{array}$ & $\begin{array}{l}100 \% \\
+0 \% \\
* 0 \%\end{array}$ & SAE 10W50 & $\begin{array}{l}150 \\
\dagger 105 \\
* 30\end{array}$ & $1 \mathrm{R}$. & Fully flooded \\
\hline 2008 & $(60)$ & $\begin{array}{l}\text { Wannatong, } \\
\text { Chanchaona et al. }\end{array}$ & 0.1 & 4 & 0.5 Diesel & 1200 & $\begin{array}{l}\text { Full } \\
5.7 \mathrm{MPa}\end{array}$ & $\begin{array}{l}0.012 \\
\text { Pa s (T_amb) }\end{array}$ & $\begin{array}{l}100 \\
\text { Liner }\end{array}$ & $3 \mathrm{R}$. & $\begin{array}{l}\text { Starved } \\
(6 \mu \mathrm{m} \text { Oil Control } \\
\text { Ring) }\end{array}$ \\
\hline 2013 & (61) & $\begin{array}{l}\text { Morris, Rahmani et } \\
\text { al }\end{array}$ & 0.1 & 2.7 & 0.5 Petrol & 2000 & $5.6 \mathrm{MPa}$ & $\begin{array}{l}55.99 \text { cSt (40C) } \\
9.59 \text { cSt }(100 \mathrm{C})\end{array}$ & $-*$ & $3 \mathrm{R}$. & $\begin{array}{l}\text { Fully Flooded } \\
\text { with *thermal }\end{array}$ \\
\hline 2014 & (62) & Yuan, Feng et al & 0.5 & 3 & 0.3 & $\begin{array}{l}\text { Free } \\
\text { Piston } \\
\text { Gen. }\end{array}$ & $8.5 \mathrm{MPa}$ & - & - & $2 \mathrm{R}$. & \\
\hline 2015 & (8) & Taylor & $0.5^{*}$ & 5.8 & 0.5 Petrol & 2500 & $3.2 \mathrm{MPa}$ & SAE 15W40 & $100-150$ & $3 \mathrm{R}$. & $\begin{array}{l}\text { Fully Flooded } \\
* \text { Squeeze }\end{array}$ \\
\hline 2015 & (63) & $\begin{array}{l}\text { Shahmohamadi, } \\
\text { Mohammadpour et } \\
\text { al }\end{array}$ & 0.7 & 10.8 & 0.5 & 1500 & - & - & - & & $\begin{array}{l}\text { Inlet flooded with } \\
\text { reversal and } \\
\text { cavitation }\end{array}$ \\
\hline 2015 & (64) & $\begin{array}{l}\text { Usman, Cheema et } \\
\text { al }\end{array}$ & 0 & $\begin{array}{l}6.5 \\
3 *\end{array}$ & 0.8 & 1000 & $6 \mathrm{MPa}$ & $\begin{array}{l}0.016 \mathrm{~Pa} \mathrm{~s} \\
\left(\mathrm{~T} \_ \text {amb) }\right.\end{array}$ & 100 & $1 \mathrm{R}$. & $\begin{array}{l}\text { Fully flooded, } \\
\text { *Distortion }\end{array}$ \\
\hline
\end{tabular}

Table 8 Compilation of published results of computer simulations. Top compression ring. 


\section{References}

1. Furuhama S. A dynamic theory of piston-ring lubrication: 1st report, calculation. Bulletin of JSME. 1959;2(7):423-8.

2. Furuhama S, Sumi T. A Dynamic Theory of Piston-Ring Lubrication : 3rd Report, Measurement of Oil Film Thickness. Bulletin of JSME. 1961;4(16):744 752.

3. Sherrington I. Oil film thickness measurement: A contribution to the understanding and control of lubrication in the piston-ring packs of IC engines. Proc Inst Mech Eng Part J. 2011;225(7):595-601.

4. Sherrington I, Smith EH. Experimental methods for measuring the oil-film thickness between the piston-rings and cylinder-wall of internal combustion engines. Tribol Int. 1985 12;18(6):315-20.

5. Taylor RI, Brown MA, Thompson DM. Lubricants and Lubrication - Proceedings of the 21th leeds-Lyon Symposium on Tribology; Validation of a Piston Ring-Pack Lubrication Model that Includes Realistic Lubricant Rheology. . 1995;30:345-54.

6. Tamminen J, Sandström C, Andersson P. Influence of load on the tribological conditions in piston ring and cylinder liner contacts in a medium-speed diesel engine. Tribol Int. 2006 12;39(12):1643-52.

7. Taylor RI, Evans PG. In-situ piston measurements. Proc Inst Mech Eng Part J. 2004;218(3):185-200.

8. Taylor R. Squeeze film lubrication in piston rings and reciprocating contacts. Proc Inst Mech Eng Part J. 2015:1350650114564234.

9. Garcia-Atance Fatjo G, Smith EH, Sherrington I. Mapping lubricating film thickness, film extent and ring twist for the compression-ring in a firing internal combustion engine. Tribol Int. 2014 2;70(0):112-8.

10. Moore S. Piston Ring Oil Film Thickness - The Effect of Viscosity. SAE Technical Paper 850439. 1985.

11. Söchting SJ, Sherrington I. The effect of load and viscosity on the minimum operating oil film thickness of piston-rings in internal combustion engines. Proc Inst Mech Eng Part J. 2009;223(3):383-91.

12. Gamble RJ, Priest M, Taylor CM. Detailed Analysis of Oil Transport in the Piston Assembly of a Gasoline Engine - Springer. Tribology Letters. 2003;14(2 February 2003):147-56. 
13. Grice N, Sherrington I, Smith EH. A Capacitance Based System for High Resolution Measurement of Lubricant Film Thicknesses. 4th Nordic Symposium on Tribology, Lubrication, Friction and Wear. Hirtshals, Denmark; 10-13 June 1990; ; 1990.

14. Ma M, Smith E, Sherrington I. A three-dimensional analysis of piston ring lubrication Part 1: Modelling. Proc Inst Mech Eng Part J. 1995;209(1):1-14.

15. Ducu D, Donahue R, Ghandhi J. Design of capacitance probes for oil film thickness measurements between the piston ring and linear in internal combustion engines. Journal of engineering for gas turbines and power. 2001;123(3):633-43.

16. Wing RD, Saunders O. Oil Film Temperature and Thickness Measurements on the Piston Rings of a Diesel Engine. Proceedings of the Institution of Mechanical Engineers. 1972;186(1):1-9.

17. Hamilton GM, Moore SL. Measurement of the oil-film thickness between the piston rings and liner of a small diesel engine. ARCHIVE: Proceedings of the Institution of Mechanical Engineers 1847-1982 (vols 1-196). 1974;188(1974):253 - 261.

18. Hamilton GM, Moore SL. Measurement of piston ring profile during running-in. Piston ring scuffing conference. IMechE, London; ; 1975.

19. Parker DA, Stafford JV, Kendrick M, Graham NA. Experimental measurements of the quantities necessary to predict piston ring-cylinder bore oil film thickness, and of the oil film thickness itself, in two particular engines. Conference on piston ring scuffing. ; 1975.

20. Brown SR, Hamilton GM. The partially lubricated piston ring. ARCHIVE: Journal of Mechanical Engineering Science 1959-1982 (vols 1-23). 1977;19(2):81 - 89.

21. Brown SR, Hamilton GM. Negative pressures under a lubricated piston ring. ARCHIVE: Journal of Mechanical Engineering Science 1959-1982 (vols 1-23). 1978;20(1):49 -57.

22. Moore SL, Hamilton GM. The starved lubrication of piston rings in a diesel engine. ARCHIVE: Journal of Mechanical Engineering Science 1959-1982 (vols 1-23). 1978;20(6):345-52.

23. Moore SL. Measurement of the ring to liner oil film thickness in a Caterpillar 1-G diesel engine. In: SAE paper 790730, Relationship Between Engine Oil Viscosity and Engine Performance, Parts 5 . SAE; 1979.

24. Moore SL, Hamilton GM. The piston ring at top dead centre. ARCHIVE: Proceedings of the Institution of Mechanical Engineers 1847-1982 (vols 1-196). 1980;194(1980):373-81. 
25. Moore SL, Hamilton GM. Ring pack film thickness during running-in. 8th LeedsLyon Symposium; ; 1981.

26. Moore SL. Piston ring lubrication in a two-stroke diesel engine. Wear. 1981 11/2;72(3):353-69.

27. Shin K, Tateishi Y, Furuhama S. Measurement of Oil-Film-Thickness Between Piston Ring and Cylinder. International Congress and Exposition, Detroit, Michigan. SAE paper 830068; ; 1983.

28. Furuhama S, Asahi C, Hiruma M. Measurement of Piston Ring Oil Film Thickness in an Operating Engine. A S L E Transactions. 1983;26(3):325 - 332.

29. Myers JE, Borman GL, Myers PS. Measurements of oil film thickness and liner temperature at top ring reversal in a diesel engine. SAE Technical PAPER 900813. 1990.

30. Richardson DE, Borman GL. Using Fiber Optics and Laser Fluorescence for Measuring Thin Oil Films with Application to Engines. SAE Technical paper 912388. 1991.

31. Mattsson C. Measurement of the oil film thickness between the cylinder liner and the piston rings in a heavy duty directly injected diesel engine. SAE 952469. 1995.

32. Yoshida H, Kobayashi H, Yamada T, Takiguchi M, Kuwada K. Effects of narrowwidth, low-tangential-tension, 3-piece oil ring on oil consumption. JSAE Rev. 2000 1;21(1):21-7.

33. Seki T, Nakayama K, Yamada T, Yoshida A, Takiguchi M. A study on variation in oil film thickness of a piston ring package: variation of oil film thickness in piston sliding direction. JSAE Rev. 2000 7;21(3):315-20.

34. Takiguchi M, Sasaki R, Takahashi I, Ishibashi F, Furuhama S, Kai R, et al. Oil Film Thickness Measurement and Analysis of a Three Ring Pack in an Operating Diesel Engine. SAE Technical Paper 2000-01-1787. 2000.

35. Weimar H, Spicher U. Crank-Angle Resolved Oilfilm Thickness Measurement Between Piston Ring and Cylinder Liner in a Spark Ignition Engine. ASME 2003 Internal Combustion Engine Division Spring Technical Conference; American Society of Mechanical Engineers; 2003.

36. Saad P, Kamo L, Mekari M, Bryzik W, Wong V, Dmitrichenko N, et al. Modeling and measurement of tribological parameters between piston rings and liner in turbocharged diesel engine. SAE Technical Paper 2007-01-1440. 2007. 
37. Mills R, Avan E, Dwyer-Joyce R. Piezoelectric sensors to monitor lubricant film thickness at piston-cylinder contacts in a fired engine. Proc Inst Mech Eng Part J. 2012(Special Issue Article):1.

38. Mills R, Vail J, Dwyer-Joyce R. Ultrasound for the non-invasive measurement of internal combustion engine piston ring oil films. Proc Inst Mech Eng Part J. 2014;229(2):207-15.

39. Ruddy B, Dowson D, Economou P, Baker A. Piston-Ring Lubrication. Part III. The Influence of Ring Dynamics and Ring Twist. Energy Conservation Through Fluid Film Lubrication Technology: Frontiers in Research And Design, ASME Winter Annual Meeting, New York, Dec; ; 1979.

40. Rohde SM, Whitaker KW, McAllister G. A Study of the Effects of Piston Ring and Engine Design Variables on Piston Ring Friction. General Motors Research Laboratories; 1979.

41. Ruddy B, Parsons B, Dowson D, Economou P. The influence of thermal distortion and wear of piston ring grooves upon the lubrication of piston rings in diesel engines. Mechanical Engineering Publications, Ltd, and Society of Automotive Engineers, Inc,. 1980:84-94.

42. Rohde SM. A mixed friction model for dynamically loaded contacts with application to piston ring lubrication. General Motors Research Laboratories; 1980.

43. Ruddy B, Economou P, Dowson D. The Theoretical Analysis of Piston Ring Performance and Its Use in Practical Ring Pack Design. CIMAC; 1981.

44. Richez M, Constans B, Winquist K. Theoretical and experimental study of ring-liner friction. 9th Leeds-Lyon Symp; ; 1982.

45. Grice N, Sherrington I, Smith EH. The Influence of Variable Ring Face Profile and Bore Shape on Piston Ring Behaviour in Internal Combustion Engines. SAE Technical Paper 920059. 1992.

46. Ma M, Smith E, Sherrington I. A Three-Dimensional Analysis of Piston Ring Lubrication Part 2: Sensitivity Analysis. Proc Inst Mech Eng Part J. 1995;209(1):15-27.

47. Ma M, Sherrington I, Smith E. Implementation of an algorithm to model the starved lubrication of a piston ring in distorted bores: prediction of oil flow and onset of gas blow-by. Proc Inst Mech Eng Part J. 1996;210(1):29-44.

48. Sanda S, Murakami M, Noda T, Konomi T. Analysis of Lubrication of a Piston Ring Package.(Effect of Oil Starvation on Oil Film Thickness). JSME International Journal Series B Fluids and Thermal Engineering. 1997;40(3):478-86. 
49. Ma M, Sherrington I, Smith EH. Analysis of lubrication and friction for a complete piston-ring pack with an improved oil availability model: Part 1: circumferentially uniform film. Proc Inst Mech Eng Part J. 1997;211(1):1-15.

50. Ma M, Smith EH, Sherrington I. Analysis of lubrication and friction for a complete piston-ring pack with an improved oil availability model: Part 2: circumferentially variable film. Proc Inst Mech Eng Part J. 1997;211(1):17-27.

51. Liu K, Xie Y, Gui C. Two-dimensional lubrication study of the piston ring pack. Proc Inst Mech Eng Part J. 1998;212(3):215-20.

52. Sawicki JT, Yu B. Analytical Solution of Piston Ring Lubrication Using Mass Conserving Cavitation Algorithm. Tribol Trans. 2000;43(4):587 - 594.

53. Priest M, Dowson D, Taylor CM. Theoretical modelling of cavitation in piston ring lubrication. Proc Inst Mech Eng Part C. 2000;214(3):435 - 447.

54. Frølund K, Schramm J, Tian T, Wong V, Hochgreb S. Analysis of the piston ring/liner oil film development during warm-up for an SI-engine. Journal of engineering for gas turbines and power. 2001;123(1):109-16.

55. Tian T. Dynamic behaviours of piston rings and their practical impact. Part 2: oil transport, friction and wear of ring/liner interface and the effects of piston and ring dynamics. Proc Inst Mech Eng Part J. 2002;216(4):229-48.

56. Piao Y, Gulwadi S. Numerical investigation of the effects of axial cylinder bore profiles on piston ring radial dynamics. ASME 2002 Internal Combustion Engine Division Spring Technical Conference; American Society of Mechanical Engineers; 2002.

57. Harigaya Y, Suzuki M, Takiguchi M. Analysis of oil film thickness on a piston ring of diesel engine: effect of oil film temperature. Journal of engineering for gas turbines and power. 2003;125(2):596-603.

58. Bolander N, Steenwyk B, Sadeghi F, Gerber G. Lubrication regime transitions at the piston ring-cylinder liner interface. Proc Inst Mech Eng Part J. 2005;219(1):19-31.

59. Harigaya Y, Suzuki M, Toda F, Takiguchi M. Analysis of oil film thickness and heat transfer on a piston ring of a diesel engine: effect of lubricant viscosity. Journal of engineering for gas turbines and power. 2006;128(3):685-93.

60. Wannatong K, Chanchaona S, Sanitjai S. Simulation algorithm for piston ring dynamics. Simulation Modelling Practice and Theory. 2008;16(1):127-46. 
61. Morris N, Rahmani R, Rahnejat H, King PD, Fitzsimons B. Tribology of piston compression ring conjunction under transient thermal mixed regime of lubrication. Tribol Int. 2013 3;59(0):248-58.

62. Yuan C, Feng H, Zuo Z, Li Y. Tribological Characteristics of Piston Ring in a Freepiston Engine for Linear Generator. Energy Procedia. 2014;61(0):979-83.

63. Shahmohamadi H, Mohammadpour M, Rahmani R, Rahnejat H, Garner CP, HowellSmith S. On the boundary conditions in multi-phase flow through the piston ring-cylinder liner conjunction. Tribol Int. 2015 10;90(0):164-74.

64. Usman A, Cheema TA, Park CW. Tribological performance evaluation and sensitivity analysis of piston ring lubricating film with deformed cylinder liner. Proc Inst Mech Eng Part J. 2015:1350650115581029. 